\title{
Glaucomys sabrinus fuscus habitat and nest box use in West Virginia with management recommendations for Kumbrabow State Forest
}

Tamara M. Terry

West Virginia University

Follow this and additional works at: https://researchrepository.wvu.edu/etd

\section{Recommended Citation}

Terry, Tamara M., "Glaucomys sabrinus fuscus habitat and nest box use in West Virginia with management recommendations for Kumbrabow State Forest" (2004). Graduate Theses, Dissertations, and Problem Reports. 2050.

https://researchrepository.wvu.edu/etd/2050

This Thesis is protected by copyright and/or related rights. It has been brought to you by the The Research Repository @ WVU with permission from the rights-holder(s). You are free to use this Thesis in any way that is permitted by the copyright and related rights legislation that applies to your use. For other uses you must obtain permission from the rights-holder(s) directly, unless additional rights are indicated by a Creative Commons license in the record and/ or on the work itself. This Thesis has been accepted for inclusion in WVU Graduate Theses, Dissertations, and Problem Reports collection by an authorized administrator of The Research Repository @ WVU. For more information, please contact researchrepository@mail.wvu.edu. 


\title{
GLAUCOMYS SABRINUS FUSCUS HABITAT AND NEST BOX USE IN WEST VIRGINIA WITH MANAGEMENT RECOMMENDATIONS FOR KUMBRABOW STATE FOREST
}

\author{
Tamara M. Terry \\ Thesis submitted to the Davis College of Agriculture, Forestry, and Consumer \\ Sciences at West Virginia University \\ in partial fulfillment of the requirements for \\ the degree of
}

Master of Science

in

Wildlife and Fisheries Resources

\author{
Craig W. Stihler \\ James T. Anderson, Ph.D. \\ John W. Edwards, Ph.D., Major Professor
}

Division of Forestry

Morgantown, West Virginia

2004

Keywords: artificial nests, central Appalachians, endangered species, Glaucomys sabrinus

fuscus, habitat use, management, nest selection, telemetry, West Virginia northern flying squirrel 


\begin{abstract}
Glaucomys sabrinus fuscus Habitat and Nest Box Use with Management Recommendations for Kumbrabow State Forest
\end{abstract}

Tamara M. Terry

Nest site selection and habitat use of the endangered West Virginia northern flying squirrel (Glaucomys sabrinus fuscus) is poorly understood. Because access to suitable nesting sites and habitats could be limiting factors, it is important to investigate these ecological requirements to further conservation efforts of the species. My study was conducted on the Kumbrabow State Forest and the MeadWestvaco Wildlife and Ecological Research Forest in Randolph County, West Virginia. I examined characteristics of 31 nest sites (22 cavity; 8 leaf; 1 undetermined) from 4 radio-collared West Virginia northern flying squirrels during the summers of 2002-2003. The nest trees used were similar $(P>0.05)$ to random trees within their homeranges. Compared to random trees, nest sites were in areas with more overstory trees and snags for both males $(P=0.050)$ and females $(P=0.021)$. Furthermore, females nested in these types of areas more than males $(P<0.001)$. My findings suggest that the West Virginia northern flying squirrel may be more of a generalist in terms of nest tree selection than previously thought, and that other factors may be more critical in managing for the species. I estimated homeranges for 2 radio-collared West Virginia northern flying squirrels. I determined 40 locations on a female flying squirrel in 2002 and 54 locations on a male flying squirrel in 2003. The female's $95 \%$ adaptive kernel homerange was 3.4 ha with a core use $(50 \%)$ area of 0.3 ha. The male's $95 \%$ adaptive kernel homerange was 24.7 ha with a core use area of 5.0 ha. These estimates are smaller than previously published G.s. fuscus homeranges. Whereas with the homerange, the female used cover types proportional $(P>0.05)$ to their availability, the male used areas closer to streams $(P=0.001)$ and grassy edge $(P=0.030)$ than was available and avoided deciduous forest $(P=0.032)$. At the local scale the female used proportionately more mixed forest and grassy edge than was available, but avoided deciduous forest, and the male used more grassy edge than was available. Across the study site the female used much less deciduous forest than was available, but both squirrels used proportionately more grassy edge than was available. The homeranges of these individuals included grassy edge adjacent to roads, which may have skewed the results. The use of mixed conifer-hardwood forests indicates that management for this forest type would benefit the subspecies.

Nest boxes have been used in West Virginia since 1986 to supply the West Virginia northern flying squirrel with additional nest sites and as a means of capturing flying squirrels during periodic checks. Despite their widespread and increasing use as a method of determining West Virginia northern flying squirrel presence, no examination has been conducted to determine their efficacy and efficiency. The success of these boxes is low (1.5\%), suggesting that naturally occurring nest sites may not be limiting in the locations. Using vegetation, elevation, and the West Virginia northern flying squirrel likelihood of presence model, I created a logistic model to predict nest box success. Although the model is significant $(P<0.001)$, it only accounts for $1.4 \%$ of the variation in success among boxes. Nest box success was variable among different categories in the probability of presence model. Nest boxes in optimal sites had greater success than marginal $(P=0.002)$ and submarginal $(P=0.008)$ sites. The presence of and number of 
flying squirrels in nest boxes differed among seasons, with most captures occurring in spring and summer. The data suggests that nest boxes are not an effective tool for capturing G.s. fuscus, and that they may underestimate the range of the species when used to determine presence.

Kumbrabow State Forest, in Randolph County, West Virginia is a 3,840 ha mostly forested tract with a mixture of forest types and a confirmed West Virginia northern flying squirrel population. Although Kumbrabow State Forest currently has northern flying squirrel habitat, with proper management, the amount of forest that could support northern flying squirrel populations could be increased. I have identified three stands (16.1 ha) in the forest that have red spruce (Picea rubens) in the understory and could become optimal West Virginia northern flying squirrel habitat if managed for montane forest characteristics. Currently, 1,359 ha (35.4\%) of Kumbrabow State Forest is considered marginal or optimal in the northern flying squirrel likelihood of presence model. With intensive management, the entire forest could be included in the model including 2,073 ha (54.0\%) as optimal and 1,767 ha (46.0\%) as marginal sites. 


\section{ACKNOWLEDGEMENTS}

I thank Dr. John Edwards and Dr. Mark Ford for showing me that there is a world outside of game animals. They took a chance on me and I hope that in spite of my countless mistakes and bouts of near panic I have managed to live up to their expectations. They have always guided me as I struggled along and tried to do my best.

I thank the West Virginia Division of Natural Resources for supplying me with not only funding, data, equipment, and field assistance, but also housing at the West Virginia Wildlife Center during field seasons. Above all else, they gave me support and encouragement while I spent my days checking empty trap lines. Craig Stihler, Jack Wallace, Barbara Breshock, Terry Jones, Rob Silvester, and Joel Harrison, in particular, were indispensable to me.

I also thank the U.S. Fish and Wildlife Service for field assistance, nest box data, and endless support. I also thank Dr. Jennifer Menzel, Dr. Michael Strager, Dr. George Seidel, Dr. John Brooks, and Dr. Jim Anderson for providing me with valuable assistance and guidance. I thank my field assistants Jane Rodrigue, Bethany Hetzel, Lyann Rubert, Dan Johnson, Jacob Vitak, and Logan Wamsley for suffering through poor satellite coverage, empty nest boxes, and long nights of telemetry. I also thank my office mates Mary Beth Manjerovic, Aaron Proctor, and Liz Osier for listening to me gripe about not having caught more flying squirrels. A big thanks to Smith for saving me at the most critical time (the very end). A special thanks to the Captain and José for their ever-present companionship during the writing process. Lastly, my family has been tremendously supportive of me and my goals. I want to thank them for not giving up on me. 


\section{TABLE OF CONTENTS}

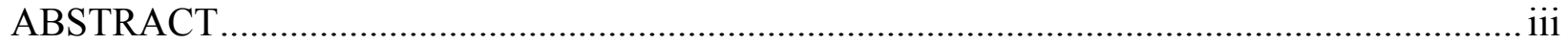

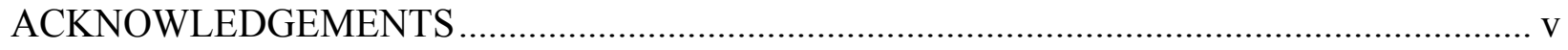

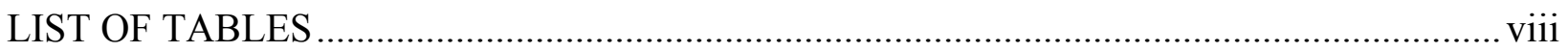

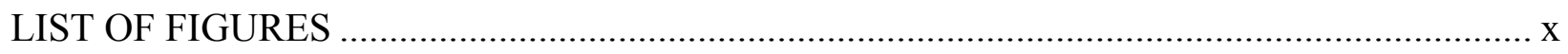

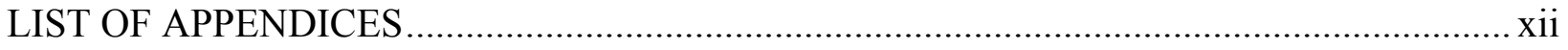

INTRODUCTION, RESEARCH JUSTIFICATION AND OBJECTIVES ................................... 1

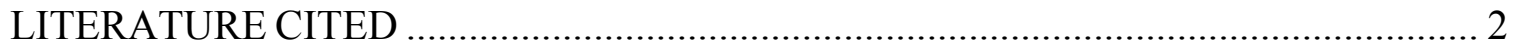

CHAPTER 1 - SUMMER NEST SITE CHARACTERISTICS AND HABITAT USE BY

GLAUCOMYS SABRINUS FUSCUS IN WEST VIRGINIA.......................................................... 4

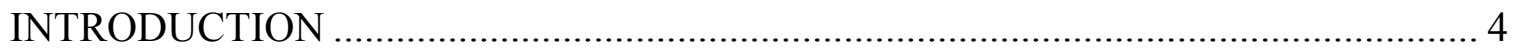

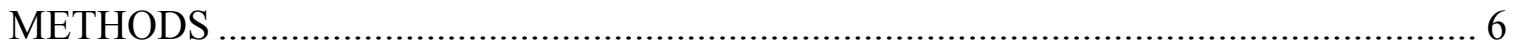

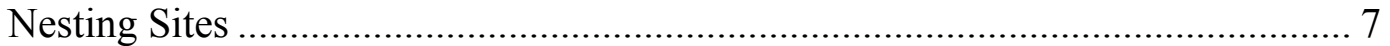

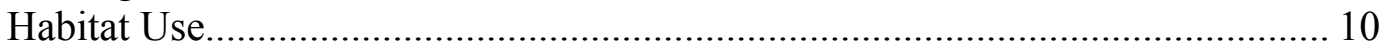

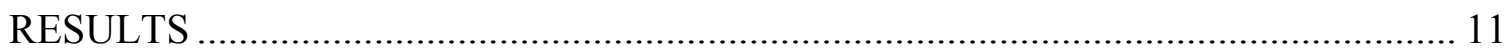

Nest Site Selection ..................................................................................... 12

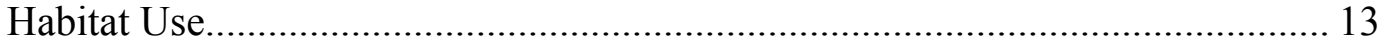

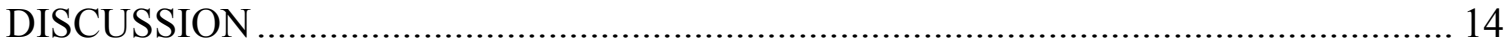

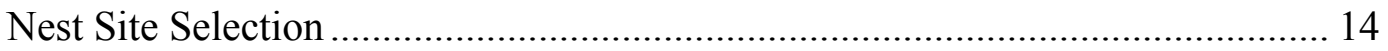

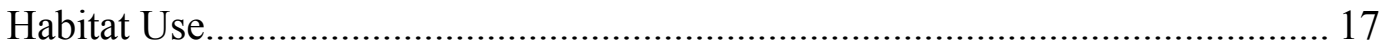

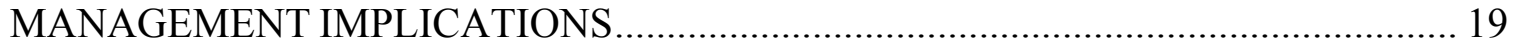

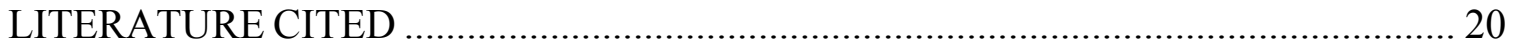

CHAPTER 2 - AN EXAMINATION OF NEST BOX OCCUPANCY BY GLAUCOMYS

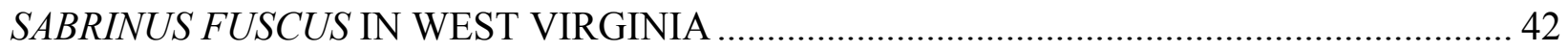

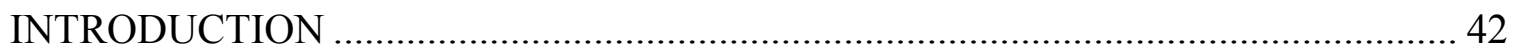

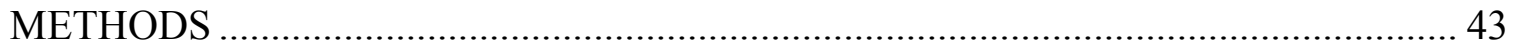

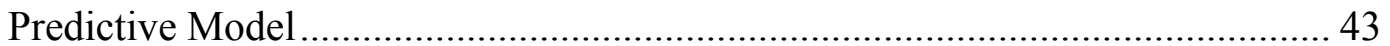

Differences Among G.s. fuscus Presence Probabilities ......................................... 44

Differences Among Seasons ................................................................................... 44

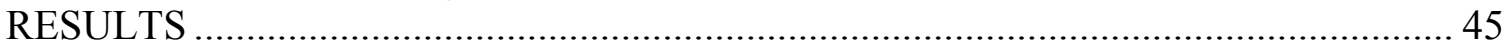

Predictive Model ..................................................................................... 45

Differences Among G.s. fuscus Presence Probabilities ......................................... 46

Differences Among Seasons .................................................................................. 46

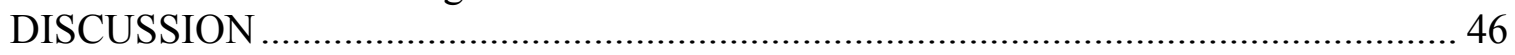

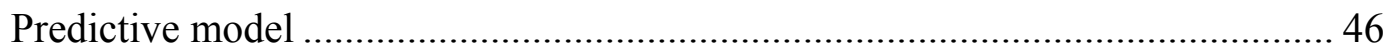

Differences Among G.s. fuscus Presence Probabilities .......................................... 48

Differences Among Seasons ………………………….................................. 49

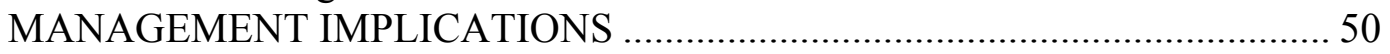

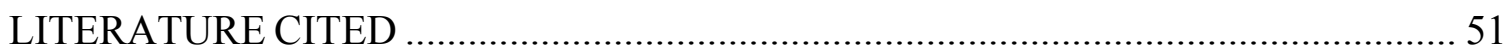


CHAPTER 3 - HABITAT MANAGEMENT RECOMMENDATIONS FOR THE ENDANGERED WEST VIRGINIA NORTHERN FLYING SQUIRREL (GLAUCOMYS

SABRINUS FUSCUS) AT KUMBRABOW STATE FOREST, WEST VIRGINIA 59

INTRODUCTION 59

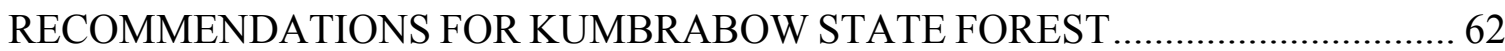

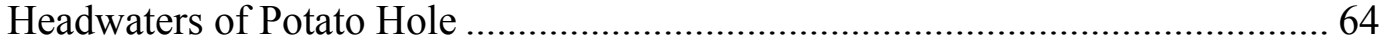

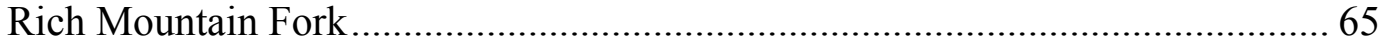

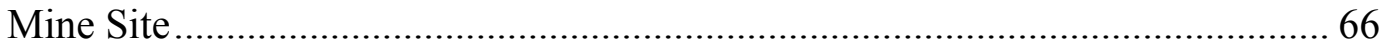

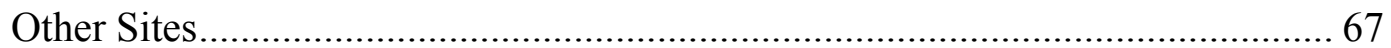

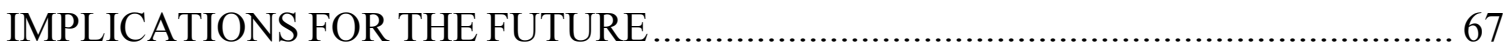

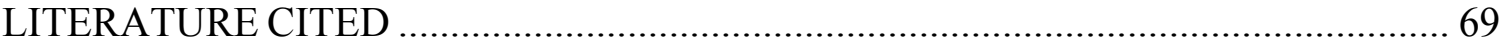




\section{LIST OF TABLES}

Table

Table 1-1. Nest sites used by Glaucomys sabrinus fuscus $(n=31)$ during the

Page summers of 2002 and 2003 in Randolph County, West Virginia.

Table 1-2. Comparison of 18 characteristics between nest trees used by Glaucomys sabrinus fuscus $(n=31)$ and random trees $(n=31)$ during the summers of 2002 and 2003 in Randolph County, West Virginia...

Table 1-3. Component loadings for principal component analysis of the characteristics of nest trees used by Glaucomys sabrinus fuscus during the summers of 2002 and 2003 in Randolph County, West Virginia.

Table 1-4. Homerange size of Glaucomys sabrinus fuscus during the summers of 2002 and 2003 in Randolph County, West Virginia.

Table 1-5. Glaucomys sabrinus fuscus habitat use at the local scale (within the homerange) during the summers of 2002 and 2003 in Randolph County, West Virginia as calculated with Euclidian distance.

Table 1-6. Habitat use at the stand and landscape scales for Glaucomys sabrinus fuscus during the summers of 2002 and 2003 in Randolph County, West Virginia. Ratios were calculated by dividing the known proportion of each cover type used by the availability at each scale.

Table 2-1. Occupancy of Glaucomys sabrinus fuscus nest boxes in West Virginia by presence probability category and results of contrasts comparing mean occupancy among presence probability categories for 363 nest boxes in West Virginia.

Table 2-2. Comparison of mean Glaucomys sabrinus fuscus nest box occupancy among seasons and results of contrasts comparing mean occupancy for 636 nest boxes in West Virginia

Table 2-3. Comparison of mean numbers of Glaucomys sabrinus fuscus found among seasons and results of contrasts comparing mean numbers among seasons from 10,850 checks of 636 nest boxes in West Virginia. 
Table 3-1. Area of Kumbrabow State Forest (3,840 ha) in Randolph County, West Virginia, that was included in the West Virginia northern flying squirrel model by J.M. Menzel (unpublished data)...............................................

Table 3-2. Size and application of West Virginia northern flying squirrel model (J.M. Menzel unpublished data) to the areas proposed for understory red spruce release at Kumbrabow State Forest in Randolph County, West Virginia. Optimal sites have an estimated $76-100 \%$ likelihood of northern flying squirrel presence....

Table 3-3. Area of Kumbrabow State Forest (3,840 ha) in Randolph County, West Virginia that could be managed for West Virginia northern flying squirrels under the model by J.M. Menzel (unpublished data).................................. 


\section{LIST OF FIGURES}

Figure

Page

Figure 1-1. Location of MeadWestvaco Wildlife Ecosystem Research Forest (MWERF) and Kumbrabow State Forest (KSF) in Randolph County, West Virginia....

Figure 1-2. Proportion of nest tree species used by West Virginia northern flying squirrels for leaf and cavity nests $(n=25)$ compared with abundance of tree species $(n=398)$ in the overstory during the summers of 2002 and 2003 on Kumbrabow State Forest and the MeadWestvaco Wildlife and Ecological Research Forest in Randolph County, West Virginia. Asterisks indicate disproportionate $(P<0.05)$ use of the species.

Figure 1-3. Eigenvalue scores for principal component 1 and principal component 2 for random sites and nest trees used by 4 radio-collared West Virginia northern flying squirrels during the summers of 2002 and 2003 on Kumbrabow State Forest and the MeadWestvaco Wildlife and Ecological Research Forest in Randolph County, West Virginia.

Figure 1-4. Homerange of West Virginia northern flying squirrel 097B including individual locations as derived from known nest sites and estimated locations $(n=$ 64), core area of use, and cover types used at Kumbrabow State Forest, Randolph

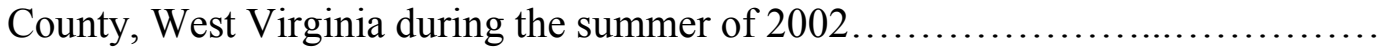

Figure 1-5. Homerange of West Virginia northern flying squirrel 076B including individual locations as derived from known nest sites and estimated locations $(n=$ 82), core area of use, and cover types used on the MeadWestvaco Wildlife and Ecological Research Forest, Randolph County, West Virginia during the summer of 2003.

Figure 2-1. Graph showing the relationship $(r=0.119, P<0.001)$ between occupancy and predicted occupancy of 363 nest boxes in West Virginia...

Figure 3-1. Location of Kumbrabow State Forest in Randolph County, West Virginia

Figure 3-2. Application of the West Virginia northern flying squirrel model (J.M. Menzel unpublished data) to Kumbrabow State Forest, Randolph County, West Virginia.

Figure 3-3. The Potato Hole area of Kumbrabow State Forest that is recommended for understory red spruce release (3.9 ha), and the West Virginia northern flying squirrel model (J.M. Menzel unpublished data).... 
Figure 3-4. The Rich Mountain Fork area of Kumbrabow State Forest that is recommended for understory red spruce release (3.6 ha), and the West Virginia northern flying squirrel model (J.M. Menzel unpublished data)....................

Figure 3-5. The Mine Site area of Kumbrabow State Forest that is recommended for understory red spruce release ( $8.6 \mathrm{ha}$ ), and the West Virginia northern flying squirrel model (J.M. Menzel unpublished data)................................

Figure 3-6. The potential West Virginia northern flying squirrel predictive presence values (J.M. Menzel unpublished data) for Kumbrabow State Forest if the entire forest were managed for overstory conifer trees. The result is 2,073 ha $(54.0 \%)$ of optimal area and 1,767 ha $(46.0 \%)$ of marginal area................... 


\section{LIST OF APPENDICES}

Appendix

Page

Appendix A. Trap arrangement of Tomahawk 201 and 202 live traps used to trap Glaucomys sabrinus fuscus at Kumbrabow State Forest during the summer of 2002. Traps were placed in 5 transects of 10 traps with not less than 5 and not more than $10 \mathrm{~m}$ between consecutive traps within the line. Each box represents

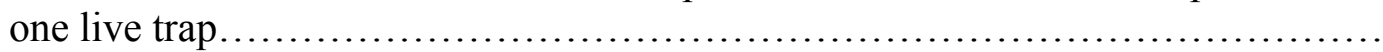

Appendix B. Trap arrangement of Tomahawk 201 and 202 live traps used to trap Glaucomys sabrinus fuscus at Kumbrabow State Forest during the summer of 2003. Traps were placed in two parallel transects with $50 \mathrm{~m}$ between consecutive traps. Transects were separated by $50 \mathrm{~m}$. Each box represents one live trap......... 


\section{INTRODUCTION, RESEARCH JUSTIFICATION AND OBJECTIVES}

The northern flying squirrel (Glaucomys sabrinus) has 25 recognized subspecies (Hall 1981, Wells-Gosling and Heaney 1984, United States Fish and Wildlife Service [USFWS] 1990). Subspecies inhabiting the central Appalachian Mountains, the West Virginia northern flying squirrel (G. s. fuscus) and the Carolina northern flying squirrel (G. s. coloratus), were listed as federally endangered in 1990 as a result of increasing habitat loss and fragmentation. A formal Recovery Plan for these subspecies was developed in 1985, completed in 1990, and revised in 2001 (USFWS 1990, 2001). Most research on northern flying squirrels has been conducted on populations in Canada and the Pacific Northwest (e.g. Hayward and Rosentreter 1994, Cotton and Parker 2000, Côté and Ferron 2001). Limited published information is available on Appalachian subspecies.

Presently, the range of the northern flying squirrel is smaller than that occupied during the Pleistocene. Since that time there have been local extirpations as the range of the species moved north with the retreating suitable habitat. As a result, populations in the central Appalachians were forced to higher elevations with the diminishing montane forests (Brown 1971). Studies suggest that older montane forests are essential for shelter and food (Payne et al. 1989, Cotton and Parker 2000). However, northern flying squirrels also may have inhabited ecotones between conifer and hardwood stands (Payne 1983). Populations of G. s. fuscus and G. s. coloratus have become progressively more isolated, thereby threatening their survival by restricting gene flow among populations and increasing the consequences of habitat loss (USFWS 1990, Weigl et al. 1999).

Two primary recovery objectives of the Appalachian northern flying squirrel recovery plan are to determine the distribution and viability of G.s. fuscus populations and to develop 
management guidelines (USFWS 1990). Consequently, the objectives of this project were to address habitat requirements of G.s. fuscus, evaluate the effectiveness of nest boxes as a method of capturing G.s. fuscus, and to propose management recommendations to increase potential G.s. fuscus habitat at Kumbrabow State Forest. Specific objectives were to:

1. determine nest site selection, homerange size, and habitat use of G.s. fuscus at Kumbrabow State Forest and the MeadWestvaco Wildlife and Ecological Research Forest at multiple spatial scales;

2. evaluate the effectiveness of the current nest box program as a means of capturing G.s. fuscus and examine nest box success across sites and seasons; and

3. propose management recommendations for G.s. fuscus habitat on Kumbrabow State Forest.

\section{LITERATURE CITED}

Brown, J.H. 1971. Mammals on mountaintops: nonequilibrium insular biogeography. American Naturalist 105:467-468.

Côté, M. and J. Ferron. 2001. Short-term use of different residual forest structures by three sciurid species in a clear-cut boreal landscape. Canadian Journal of Forest Resources $31: 1805-1815$.

Cotton, C.L. and K.L. Parker. 2000. Winter habitat and nest trees used by northern flying squirrels in subboreal forests. Journal of Mammalogy 81(4):1071-1086.

Hall, E.R., editor. 1981. The mammals of North America. Second edition. Wiley Publishing, New York, New York, USA.

Hayward, G.D., and R. Rosentreter. 1994. Lichens as nesting material for northern flying squirrels in the northern Rocky Mountains. Journal of Mammalogy 75(3):663-673. 
Payne, J.L. 1983. Habitat variation among montane island populations of the flying squirrel, Glaucomys sabrinus in the Central Appalachian Mountains. M.S. Thesis, Virginia Commonwealth University, Richmond, Virginia, USA.

, D.R. Young, and J.F. Pagels. 1989. Plant community characteristics associated with the endangered northern flying squirrel, Glaucomys sabrinus, in the Central Appalachians. American Midland Naturalist 121:285-292.

U.S. Fish and Wildlife Service. 1990. Appalachian Northern Flying Squirrels (Glaucomys sabrinus fuscus and Glaucomys sabrinus coloratus) Recovery Plan. Newton Corner, Massachusetts, USA.

.2001. Appalachian Northern Flying Squirrels (Glaucomys sabrinus fuscus and Glaucomys sabrinus coloratus) Updated Recovery Plan. Newton Corner, Massachusetts, USA.

Weigl, P.D., T.W. Knowles, and A.C. Boynton. 1999. The distribution and ecology of the northern flying squirrel, Glaucomys sabrinus coloratus, in the southern Appalachians. North Carolina Wildlife Resources Commission, Raleigh, North Carolina, USA.

Wells-Gosling, N. and L.R. Heaney. 1984. Glaucomys sabrinus. Mammalian Species No.229: $1-8$. 
CHAPTER 1 - SUMMER NEST SITE CHARACTERISTICS AND HABITAT USE BY GLAUCOMYS SABRINUS FUSCUS IN WEST VIRGINIA

\section{INTRODUCTION}

Northern flying squirrels (Glaucomys sabrinus) in the central Appalachian Mountains have gained increased attention in recent years. The West Virginia northern flying squirrel (G. $s$. fuscus) and the Carolina northern flying squirrel (G. s. coloratus) were listed as federally endangered in 1985 as a result of increasing habitat loss and fragmentation. A formal Recovery Plan for these subspecies was developed in 1985, completed in 1990, and revised in 2001 (USFWS 1990, 2001). G.s. fuscus, which occurs in disjunct communities in the mountainous regions of eastern West Virginia and western Virginia, may be especially vulnerable to population declines. Most research on northern flying squirrels has been conducted on populations in Canada and the Pacific Northwest (e.g. Hayward and Rosentreter 1994, Cotton and Parker 2000, Côté and Ferron 2001), and limited published information is available on G.s. fuscus.

West Virginia northern flying squirrels face several threats to their survival. Capture sites in Virginia and West Virginia indicate a close association with high elevation spruce forests where red spruce (Picea rubens) and eastern hemlock (Tsuga canadensis) are prevalent in the overstory (Urban 1988, Payne et al. 1989, Menzel et al. 2004). Unfortunately, this forest type is considered among the most rare and threatened forested ecosystems in the United States (White et al. 1993, Christensen et al. 1996). Threats to G.s. fuscus habitat include exotic insect pests, acid precipitation, and habitat fragmentation and loss to recreational and second home development (USFWS 1990). Moreover, competition with the southern flying squirrel ( $G$. volans), as well as parasitism by the nematode, Strongyloides robustus, carried by G. volans, 
may threaten G.s. fuscus populations in areas of sympatry (Weigl 1975, 1978; Webster et al. 1985; Fies and Pagels 1991).

Northern flying squirrels use both cavity and leaf nests. G.s. fuscus inhabits cavities excavated by pileated (Dryocopus pileatus) or other woodpeckers (Hamilton 1943, Aitken et al. 2002). They also construct and use leaf nests, often in overstory trees (Cowan 1936, Weigl and Osgood 1974, Urban 1988, Menzel et al. 2004). G. sabrinus has even been observed using subterranean nests (Wells-Gosling and Heaney 1984, Carey et al. 1997, Weigl et al. 2002, Hackett and Pagels 2003). Nests are lined or constructed with shredded bark, dry leaves, moss, feathers, fur, or other soft materials (Walker et al. 1964).

Estimates of West Virginia northern flying squirrel homeranges vary among studies. Urban (1988) estimated small summer and fall homeranges for adult males (5.2 ha). However, Menzel (2003) estimated average summer homeranges of 64.1 ha for males and 17.0 ha for females. Similar studies conducted on G.s. coloratus found summer homeranges as small as 2.0 ha and winter homeranges as large as 17.4 ha (Weigl and Osgood 1974, Weigl et al. 2002)

G.s. fuscus is considered a habitat specialist in association with mature, high elevation coniferous forests (Payne et al. 1989, Cotton and Parker 2000). Odom et al. (2001) found distance to conifer cover and elevation significantly associated with G.s. fuscus presence when comparing among occupied, unoccupied, and random sites. Payne (1983) trapped G. s. fuscus and G.s. coloratus in Virginia, Tennessee, and North Carolina more often in ecotones between conifers and hardwoods than in one particular forest type. These ecotones were characterized by yellow birch (Betula allegheniensis), American beech (Fagus grandifolia), sugar maple (Acer saccharum), hemlock, red spruce, and balsam fir (Abies balsamea; USFWS 1990). In West Virginia, Stihler et al. (1995) reported G.s. fuscus occurrence in stands typified by open 
understories with scattered, large-diameter conifers, deciduous trees, and snags with cavities. G.s. fuscus also has been found in areas outside of spruce forests (Payne 1983, Stihler 1985, Weigl et al. 1999), including a 2004 capture in West Virginia at an elevation less than $900 \mathrm{~m}$ (C.W. Stihler, West Virginia Division of Natural Resources (WVDNR), personal communication).

Although several studies have investigated the ecological requirements of G.s. fuscus, there remains a dearth of information regarding nest site selection and habitat use. In recent years, there has been increasing interest in restoring West Virginia's high elevation mixed forests. However, to manage these forests for relict populations of West Virginia northern flying squirrels, wildlife managers must know what forest characteristics are desirable to the species. The objective of this study was to quantify further the characteristics of G.s. fuscus nest sites and areas of use. This information will be important in future habitat conservation and restoration efforts.

\section{METHODS}

My study was conducted from May to August 2002 and May to September 2003 on Kumbrabow State Forest (KSF) and the MeadWestvaco Wildlife and Ecological Research Forest (MWERF). These adjacent sites are part of the Allegheny Mountain and Plateau physiographic sub-province in Randolph County, West Virginia, near the town of Helvetia (Fig. 1).

The region is characterized by steep ridges running southwest to northeast. The area is mostly Allegheny northern hardwood forest, characterized by red maple (A. rubrum), sugar maple, yellow birch, American beech, Fraser magnolia (Magnolia fraseri), and black cherry (Prunus serotina; Stephenson 1993). Most northern hardwood-red spruce and red sprucehemlock forests are found at elevations over $900 \mathrm{~m}$ (Bailey and Ware 1990, Stephenson 1993). 
KSF and the MWERF comprise almost 7,300 ha of mostly mixed hardwood-conifer forests (49.8\%) and deciduous forests (43.7\%). The MWERF is an intensively managed research forest set aside for the study of timber practices and their effects on wildlife populations. Timber practices on the MWERF include commercial thinnings, diameter-limit harvests, deferment harvests, and clearcuts. The forest is a complex matrix of differing cover types and stand ages ranging from young clearcuts to mature forests. KSF is less complex and primarily is covered with second-growth northern hardwood forest and mixed hardwood-conifer forest 70 to 100 years old. Although several streams traverse the area, there is little standing water present on either site with the exception of a few small sphagnum (Sphagnum spp.) bogs. Elevation ranges from 700 to $1,195 \mathrm{~m}$. The site has a cool temperate climate with average summer and winter temperatures of $23^{\circ} \mathrm{C}$ and $0^{\circ} \mathrm{C}$, respectively and average annual rainfall of $159 \mathrm{~cm}$ and average snowfall of $325 \mathrm{~cm}$ (M. Yaeger, Kumbrabow State Forest, personal communication).

\section{Nesting Sites}

I captured West Virginia northern flying squirrels using Tomahawk ${ }^{\circledR}$ Model 201 and Model 202 live traps (Tomahawk Live Trap, Tomahawk, Wisconsin). Nine sites on KSF were trapped during the study. I chose trap sites based on physiographic and vegetational characteristics similar to areas known to be occupied by G.s. fuscus (W.M. Ford, United States Forest Service, and C.W. Stihler, WVDNR, personal communication). These sites were characterized by overstory red spruce trees, an abundance of snags, and moist forest floor. In 2002, I arranged traps in 5 rows of 10 traps radiating out at $5 \mathrm{~m}$ intervals from a central point (Appendix A). In 2003, I arranged traps in transects consisting of 20 to 30 traps in 1 or 2 lines with $50 \mathrm{~m}$ between traps and transects (Appendix B). I placed traps on the ground with polyester-cotton batting for added warmth (Cotton and Parker 2000, Menzel et al. 2004) and 
baited them with a mixture of rolled oats, peanut butter, and molasses (USFWS 1990, Menzel et al. 2004). To decrease the possibility of mortality due to exposure, I opened traps only on nights with no expected precipitation and minimum temperatures above $7^{\circ} \mathrm{C}$. Traps were set at approximately $1900 \mathrm{~h}$ and checked at $0700 \mathrm{~h}$ the following morning. Traps were opened for 10 nights and then removed (USFWS 1990). In addition, there were 50 nest boxes on the MWERF and 84 on KSF that were checked periodically for G.s. fuscus presence. These nest boxes were placed by WVDNR personnel for long-term monitoring of G.s. fuscus populations.

I transferred captured flying squirrels to a nylon mesh bag for handling. I recorded mass using a spring scale, hind foot length, gender, age, and reproductive condition. G.s. fuscus was identified by the hind foot length $(>33 \mathrm{~mm}$ ) and the gray base of the ventral pelage (WellsGosling and Heaney 1984). Age was determined by examination of mass and pelage (Witt 1992). Each squirrel was ear tagged with a uniquely numbered Monel $^{\circledR}$ No. 2 ear tag (National Brand and Tag Company, Newport, Kentucky). Adult squirrels $\geq 75 \mathrm{~g}$ were transferred to a $5.4 \mathrm{~L}$ plastic storage box containing a cotton ball saturated with Halothane (Halocarbon Laboratories, River Edge, New Jersey). Once anesthetized, individuals were fitted with a Holohil ${ }^{\circ}$ PD-2C transmitter (Holohil Systems, Ltd., Ontario, Canada) unit mounted on a plastic cable tie covered with plastic tubing to reduce possible neck abrasion. In 2003, I included a piece of cotton thread saturated with Tobasco $^{\mathbb{O}}$ sauce within the tubing to deter chewing of the collar by conspecifics. Each collar unit weighed approximately $4 \mathrm{~g}$ and had an estimated battery life of 24 weeks.

Following a one-day acclimation period, I routinely monitored radio-collared flying squirrels to determine nest site selection, nest fidelity, and movement patterns. I used a TRX2000S PLL synthesized tracking receiver (Wildlife Materials, Inc., Carbondale, Illinois) and a 3element Yagi antenna to track flying squirrels to their diurnal nests. Coordinates were recorded 
for each nest tree using a Trimble GeoExplorer III Global Positioning System (Trimble Navigation Limited, Sunnyvale, California). Each nest site was identified by tree species, marked, and described as a cavity nest, leaf nest, nest box, or undetermined.

I conducted vegetation sampling to study habitat characteristics around nests. Nest sites were centered within an $11.4 \mathrm{~m}$ radius ( $0.04 \mathrm{ha})$ vegetative plot. I recorded the following metrics at each plot: elevation, slope, height and diameter at breast height (DBH) of the overstory trees, snags, and nest tree and percent cover of overstory, midstory, understory, seedlings, forest floor vegetation, rocks, and moss. Trees were considered overstory if they were of dominant or codominant crown class (Smith 1986). Percent cover of overstory, midstory, understory, seedlings, forest floor vegetation, rocks, and moss was estimated by ocular estimation.

I assigned a paired random tree to each nest tree. I selected random trees by walking $50 \mathrm{~m}$ in a random direction from the nest tree and choosing the first tree that contained a cavity or would support a leaf nest, depending on type of nest tree (Cotton 1999). Coordinates for the random tree were recorded and similar vegetation sampling conducted.

I used Fisher's exact test to determine if nest tree species used were in proportion to availability by comparing them with random trees and also to overstory trees available within vegetation plots. Fisher's exact test was used because I had instances of less than 5 observations (Dowdy and Wearden 1991). I conducted paired $t$-tests to determine habitat variable differences between nest trees and random trees. Principal components analysis was used to find further differences between nest and random sites and among nest sites. A significance level of 0.05 was used for all statistical tests. 


\section{Habitat Use}

Radio telemetry was used to determine movement patterns and habitat use of the radiocollared G.s. fuscus. Azimuths were taken simultaneously every 15 minutes from 2 locations with known Universal Transverse Mercator (UTM) coordinates (White and Garrott 1990). Researchers maintained contact via 2-way radios to ensure that azimuths were taken simultaneously. Azimuths were recorded at approximately $90^{\circ}$ to minimize error (White and Garrott 1990). I calculated the error associated with locations by determining the average difference between recorded azimuths and known locations of transmitters hidden in the field (Hurst and Lacki 1999). The resulting error arc was $\pm 3^{\circ}$ and the error polygon was 0.015 ha at $100 \mathrm{~m}$ distance from the transmitter. Data were collected between $2000 \mathrm{~h}$ to $0600 \mathrm{~h}$. Locational data were not collected during rain events.

Telemetry data were entered into program LOCATE to obtain UTM coordinates for animal locations (Kie et al. 1996). The output locations then were entered into ArcGis ${ }^{\circledR}$ (Environmental Systems Research Institute, Redlands, California) for use in the Animal Movements and Spatial Analyst Extensions (ESRI 1994, Hooge and Eichenlaub 1997) to estimate homeranges. Homeranges were estimated only for those individuals with $\geq 30$ estimated locations. Diurnal nest site locations were included in individual homerange estimates. I used the Adaptive Kernel (AKM) homerange estimator (95 and 50\% confidence intervals) and minimum convex polygon (MCP) to estimate the homerange and core area of use. Estimated homeranges were overlaid with digitized vegetation coverage of the study area to determine proportions of each cover type used.

I calculated habitat use by radio-collared flying squirrels by comparing cover types used to those available at 3 spatial scales: local, stand, and landscape. The local scale was defined as 
the estimated homerange of the individual; stand scale was a $2-\mathrm{km}$ radius around the capture site (Menzel 2003); and landscape scale was the entire area of the MWERF and KSF. I evaluated habitat use at the local scale with euclidian distance analysis (Conner and Plowman 2001). In addition to distance to nearest land cover types, distance to the nearest stream was used in the calculations of habitat use at the local scale. Habitat use at the stand and landscape scales were evaluated by calculating a ratio of known proportions of different cover types used to those available at each scale. Cover types classified for the study area were grassy edge (including powerline right-of-ways, wildlife openings, and herbaceous areas along roadsides), deciduous forest, mixed hardwood-conifer forest, clearcut (including deferment and leave tree harvests), and open water.

\section{RESULTS}

Trapping and nest box checks in 2002 and 2003 resulted in the capture of 4 adult (2 male, 2 female) and 3 juvenile ( 2 male, 1 female) G.s. fuscus. In 2002, 3 adults ( 2 female, 1 male) and 3 juveniles were captured at KSF. In 2003, a male flying squirrel was captured at the MWERF. All flying squirrels, except squirrel 280A (adult male), were captured in nest boxes. No individuals were recaptured.

Other species captured in traps included red squirrels (Tamiasciurus hudsonicus, 43), chipmunks (Tamias striatus, 10), striped skunks (Memphitis memphitis, 2), Allegheny woodrats (Neotoma magister, 2), gray squirrels (Sciurus carolinensis, 2), Virginia opossum (Didelphis virginiana, 1$)$, southern flying squirrels ( $G$. volans, 1$)$, and raccoons (Procyon lotor, 1). Nest box checks resulted in captures of southern flying squirrels (5), deer mice (Peromyscus maniculatus, $3)$, and red squirrels (2 females with litters). 
Sufficient locations $(\geq 30)$ for estimating homerange were obtained for 2 of 4 radiocollared flying squirrels. I suspect that conspecifics chewed the radio-collar units, therefore resulting in a decrease in their effectiveness or their removal from the individual. Twenty-five days after his capture, flying squirrel 076B was observed without the antenna from his radiocollar unit. This was the only confirmed loss of an antenna.

\section{Nest Site Selection}

Radio-collared flying squirrels were tracked to 31 different nest sites (Table 1). Of the nest sites used, $16(51.6 \%)$ were in natural cavities, $8(25.8 \%)$ were in leaf nests, $6(19.4 \%)$ were in nest boxes, and $1(3.2 \%)$ was of an undetermined type. Flying squirrel $280 \mathrm{~A}$ (male) was tracked to 4 den sites over 16 days. Flying squirrel WV344 (female) was tracked to 2 den sites, then preyed upon. Individual 097B (female) used 12 different dens over 24 days. Flying squirrel 076B (male) was tracked to 13 dens over 27 days.

Mean nest fidelity for 097B, 076B, and 280A was 2.38 nights per nest (range 2-2.75). Flying squirrels 097B and WV344 both used nest boxes 19 and 20 during 2002. Flying squirrel 097B used one nest box for 4 consecutive nights, but never returned to it. Squirrel 076B used a nest of undetermined type in an overstory red maple for 4 consecutive nights, used other nests for 2 nights, and then returned to the first nest for 4 more consecutive nights. The mean number of nests used by males was 8.5 (range 4-13) and was 7 (range 2-12) for female flying squirrels. The pooled mean number of nests per individual was 7.75 .

I found flying squirrel cavity and leaf nests in 8 tree species; Fraser magnolia $(n=9)$, red spruce $(n=5)$, yellow birch $(n=3)$, red maple $(n=3)$, black birch $(n=2)$, Norway spruce (Picea abies, $n=1)$, eastern hemlock $(n=1)$, and basswood (Tilia heterophylla, $n=1)$. Tree species selected for nest sites were similar $(P>0.05)$ to the random trees, but were not in proportion to 
availability within the homerange $(P<0.001$, Fig. 2$)$; red maple was used less $(P=0.026)$ than available and Fraser magnolia was used more $(P=0.004)$.

Nest sites selected by radio-collared flying squirrels were similar to random sites (Table 2). Principal components analysis returned differences between nest trees and random trees, and among the nest trees. Principal component 1 (PC1) was defined as increasing elevation and number and basal area of overstory trees and snags, and decreasing height of overstory trees, slope, DBH of the den tree, and percent rock cover (Table 3). Principal component 2 (PC2) was defined as increasing height and DBH of the nest tree and distance to the nearest overstory tree, and a decreasing percent of midstory cover. There were no differences between nest trees and random trees $(\mathrm{PC} 1 P=0.9996, \mathrm{PC} 2 P=0.325)$. However, there were differences when the nest trees were separated by gender (Fig. 3). Both males $(P=0.050)$ and females $(P=0.021)$ used areas with greater numbers and basal area of overstory trees and snags than was available. Nest site use between genders showed significantly greater use by females of areas with increased numbers and basal area of overstory trees and snags $(P<0.001)$.

\section{Habitat Use}

I obtained sufficient locations on flying squirrel 097B (40 locations) and flying squirrel 076B (54 locations) to estimate homerange and habitat use. Female 097B had a 95\% adaptive kernal homerange of 3.4 ha and a core area (50\%) of 0.3 ha (Fig. 4); male $076 \mathrm{~B}$ had a 95\% homerange area of 24.7 ha and a core area of 5.0 ha (Table 4, Fig. 5). Minimum convex polygon homerange size was 2.9 ha for squirrel $097 \mathrm{~B}$ and 29.5 ha for squirrel 076B.

Although no open water was present on the study site, flying squirrel 097B, at the stand scale, had open water available on the adjacent property. Similarly, flying squirrel 076B had a clearcut present at the stand scale, but squirrel 097B did not. A clearcut was adjacent to squirrel 
076B's estimated homerange, so it was used for calculations at the local scale. No pure conifer stands were available on the site.

Flying squirrels differed in their habitat use at the local scale (Table 5). Whereas female 097B used habitats proportional to availability, male 076B used deciduous forest $(P=0.032)$ less than was expected, but grassy edge $(P=0.030)$, and areas close to streams $(P=0.001)$ more than was expected.

Habitat use analysis at the stand and landscape scales yielded similar results between individuals (Table 6). At the stand scale, female 097B used mixed northern hardwood-conifer forests (5.0:1) and grassy edge (5.2:1) more than was available, whereas deciduous forest was used less $(0.04: 1)$ than was available. Similarly, male 076B used grassy edge habitats more than was available (21.3:1) at the stand scale. At the landscape scale, female 097B again used more grassy edge than was available (9.2:1) and used deciduous forest less than was expected (0.1:1). Again, male 076B used more grassy edge than was expected (9.8:1).

\section{DISCUSSION}

\section{Nest Site Selection}

Flying squirrels on the MWERF and KSF used predominantly (78\%) natural cavities (52\%) and leaf nests (26\%). Menzel et al. (2004) reported similar findings on the MWERF and in nearby Monongahela National Forest sites where they found $69 \%$ of nests in natural cavities and $31 \%$ in leaf nests. Although no winter nest use data for West Virginia are available, these findings contrast with Cowan's (1936) suggestion that tree cavities are used primarily during winter months and leaf nests are used during summer. Urban (1988) found G.s. fuscus using leaf nests exclusively during summer. 
Northern flying squirrels are known to switch nests frequently (Urban 1988, Gerrow 1996, Carey et al. 1997, Martin and Anthony 1999, Cotton and Parker 2000, and Menzel et al. 2004). Nest fidelity on KSF and the MWERF was 2.38 nights/nest which is lower than 4.2 nights/nest reported by Menzel et al. (2004). Moreover, squirrels on KSF and the MWERF averaged more nests/animal (9.7) than previously reported for G. sabrinus. Previous reports range from 5.6 in British Columbia (Cotton and Parker 2000) to 6.1 nests/animal in Oregon (Carey et al. 1997).

Supplemental cavities provided by the nest boxes may play a role in the nest selection of the radio-collared flying squirrels, as each used nest boxes at least once. The 2 known nests of WV344 were in nest boxes. She was rearing a litter of 3 in the first, and then moved them to the other nest box following researcher disturbance. Both of these nest boxes had been used previously by 097B. This is in contrast to the findings of Mowery and Zasada (1984) who found no radio-collared northern flying squirrel using a nest after another had used it previously. Squirrel 076B was captured in a nest box, but used only natural cavities and leaf nests for the remainder of the study. Menzel et al. (2004) found no use of nest boxes by 13 G.s. fuscus in West Virginia although they were present on their study area.

Although the tree species used by the flying squirrels as leaf and cavity nest sites were similar to random trees, they did not represent overstory tree species availability within the homerange. Red maple was used as a nest tree less than was available. Although susceptible to decay, red maple does so at a slower rate than many of the other hardwood species available (e.g., yellow birch, basswood, Fraser magnolia) so it provides fewer cavities for nests (Wenger 1984). Red maples may be selected against as leaf nest locations because their open crowns are more exposed than conifer crowns, thereby exposing the flying squirrels and nest to the elements 
and increasing the likelihood of predation. Fraser magnolia, however, was used proportionately more than was available. Fraser magnolia has a high rate of decay and often an abundance of cavities (Wenger 1984). All tree species used by flying squirrels for cavity nests (red maple, yellow and black birch, and Fraser magnolia) decay at a high rate (Wenger 1984). Menzel et al. (2004) also found G.s. fuscus in West Virginia using red maple less and Fraser magnolia more than was available. In addition, they found that yellow birch was used proportionately more than was available. Although yellow birch in this study was the third most common species used, its use was proportional to availability.

The tree species selected for leaf nests were similar to those available. Spruce (mostly red spruce) was a major overstory component in all of the vegetative plots. The Norway spruce that contained a leaf nest was in a 70-year-old Norway spruce plantation adjacent to a mixed forest. With the exception of one leaf nest in an overstory basswood, all $(n=8)$ leaf nests were in the crowns of overstory conifer trees (red spruce, Norway spruce, and eastern hemlock). G. sabrinus use of overstory spruce trees for leaf nests has been documented in previous studies (Urban 1988, Cotton and Parker 2000, Menzel et al. 2004).

I found no differences between the characteristics of nest sites and random sites. Other $G$. sabrinus studies also have failed to detect differences between nest sites and random sites (Payne 1987, Urban 1988, Payne et al. 1989, Rosenberg 1990, McDonald 1995, Cotton and Parker 2000). Menzel et al. (2004) reported that elevation, tree height, cavity height, nest tree DBH, average overstory height, and average snag height were significantly greater for nest trees than random trees. They also found that nest tree decay class, number of overstory trees, seedling cover, and distance to nearest trail were significantly lower for the random trees. I selected my random trees using a different method than Menzel et al. (2004), and this difference could 
account for the differences in our results. My random trees were much closer to the nest trees than the random trees selected by Menzel et al. (2004). The lack of differences between nest sites and random sites reported here could indicate that the species is somewhat plastic in its choice of nest sites. Also, it suggests that nest sites are not limiting G.s. fuscus populations on the sites.

The selection of areas of increased numbers of snags and overstory trees could be linked to nest site and food availability. Areas with these characteristics inherently will have more potential nest sites and the microhabitat is more suited for fungi and lichens (Loeb et al. 2000, Mitchell 2001). An abundance of potential nest sites supplies the flying squirrels with refugia to escape predators or the sudden unsuitability of a nest (e.g. pooled water from rain events, parasite infestation, or researcher disturbance).

Female use of areas with increased numbers of overstory trees and snags could be a result of reproductive drive and food availability. Presumably, a female might select areas with these characteristics to enhance the potential of successfully rearing her young. Although a female $G$. sabrinus with a litter tends not to switch nests frequently (Mowrey and Zasada 1984, Menzel et al. 2004), she may opt to move them to a new nest after a disturbance. This could explain why flying squirrel WV344 moved her litter to a new nest after her capture. Having an abundance of potential nests and food available in an area would decrease the time a female must be apart from her litter to feed or find a new suitable nest.

\section{Habitat Use}

Homerange estimates reported here are similar to previously published estimates for G.S. fuscus in West Virginia. Male homerange size (AKM 24.7 ha, MCP 29.5 ha) was greater than estimated by Urban (1988), but less than was reported by Menzel (2003). Urban's average male MCP homerange was 5.2 ha $(n=3)$, and Menzel's (2003) average was 66.8 ha $(n=3)$. My AKM 
estimate, also, was less than Menzel's (2003) average of 64.1 ha. In addition, the estimated homerange of my female was less than the estimate reported by Menzel (2003). Whereas Menzel (2003) reported her average AKM homerange size to be 17.0 ha $(n=7)$, my estimated homerange size was 3.4 ha. These previous studies involved radio-tracking flying squirrels for longer periods than was conducted in my study. Each of the individual flying squirrels I estimated homerange size for was tracked for approximately 5 weeks. If more locations had been estimated for the individuals, then perhaps the estimated homerange sizes would have been larger. Tracking the flying squirrels over a longer time period could have included sudden movements from the usual area, as was seen for 2 of the radio-collared individuals during the study. Flying squirrel 076B, in particular, probably used a homerange larger than was estimated. Several nights during the study he outdistanced the effective receiver range. This same limitation was encountered by Weigl et al. (1999) and Weigl and Osgood (1974) when tracking G.s. coloratus in North Carolina and Tennessee.

Male and female flying squirrel habitat use differed at the local level. Whereas female 097B used all habitat types in proportion to availability, male 076B selected mixed forest and did not use a nearby clearcut. As G.s. fuscus is not known to use clearcuts and the clearcut was not part of the homerange, his non-use of the area was expected. These findings are similar to Menzel (2003) who, using a comparison of proportion of habitat used to what was available, found little G.s. fuscus selection of cover types.

The inclusion of grassy edge habitat at the stand and landscape levels reported here is greater than has been previously reported. Flying squirrels in this study were found to cross the nearest road, which would take them across the grassy edge habitat associated with the roadside. Flying squirrel 076B's homerange also included a small grassy area that was adjacent to the road 
(Fig. 3). Squirrel 097B's homerange included a powerline right-of-way that separated 2 patches of forest (Fig. 4). She used forests on either side of the right-of-way, therefore resulting in its inclusion in the estimated homerange. Another reason for this perceived use of grassy edge habitat is that although it was available at the local level, forests dominate most of the study site. The flying squirrels most likely are not utilizing the grassy areas, but merely are crossing them to reach the nearby forest. The close proximity to the grassy edge could be a result of nest box placement. Both of these flying squirrels were captured in nest boxes. The nest box where squirrel 097B was captured was approximately $5 \mathrm{~m}$ from the edge of the grassy edge, and squirrel $076 \mathrm{~B}$ 's capture site was approximately $35 \mathrm{~m}$ from the roadside.

At the stand and landscape scales, my northern flying squirrels used both mixed forests and grassy edge habitats proportionately more than was available, but avoided deciduous forests. These findings differ from those reported by Menzel (2003) at the stand level scale. She reported no differences at the stand scale from randomly assigned areas using principal components analysis. However, our findings are similar at the landscape scale. We both report a preference for the mixed forests and an avoidance of deciduous forests, but whereas my results indicate a selection of grassy edge habitats, she found an avoidance of such open areas. The sites on which she conducted her research were less fragmented with road and trail networks and the mixed conifer-hardwood forests were more expansive and contiguous than KSF and the MWERF.

\section{MANAGEMENT IMPLICATIONS}

Throughout its range, G.s. fuscus is found in small highly isolated patches of high elevation conifer or mixed forests. Managing for the expansion and linking of these forests would not only increase the amount of area available to the flying squirrels, but also enable the disjunct populations to disperse and interbreed more easily. Management for mature mixed 
forests would inherently increase nesting potential for the West Virginia northern flying squirrel because forests such as these have a greater abundance of hardwood snags and tall conifers than younger forests of the same type. These forests also are characterized by large downed wood and a moist forest floor, which are necessary for the proliferation of the hypogeous and epigeous fungi consumed by G.s. fuscus (Loeb et al. 2000). Evidence suggests that the West Virginia northern flying squirrel might benefit from management practices that would release understory red spruce while maintaining standing snags and an open understory for effective gliding. With proper practices, forests that have not had G.s. fuscus since logging began in the early 1900s could once again become northern flying squirrel habitat.

\section{LITERATURE CITED}

Aitken, K.E.H, K.L. Wiebe, and K. Martin. 2002. Nest-site reuse patterns for a cavity-nesting bird community in interior British Columbia. The Auk 119(2):391-402.

Bailey, C.M. and S. Ware. 1990. Red spruce forests of Highland County, Virginia: biogeographical considerations. Castanea 55:245-258.

Carey, A.B., T.M. Wilson, C.C. Maguire, and B.I. Biswell. 1997. Dens of northern flying squirrels in the Pacific northwest. Journal of Wildlife Management 61:684-699.

Christensen, N.I., A.M. Bartuska, J.H. Brown, S. Carpenter, C.D. D’Antonio, R. Francis, J.F. Franklin, J.A. MacMahon, R.F. Noss, D.J. Parsons, C.H. Peterson, M.G. Turner, and R.G. Woodmansee. 1996. The report of the Ecological Society of America Committee on the scientific basis for ecosystem management. Ecological Applications 6:665-691. 
Conner, L.M. and B.W. Plowman. 2001. Using euclidean distances to assess nonrandom habitat use. Pages 275-290 in J.J. Millspaugh and J.M. Marzluff, editors. Radio Tracking and Animal Populations. Academic Press, Orlando, Florida, USA.

Côté, M. and J. Ferron. 2001. Short-term use of different residual forest structures by three sciurid species in a clear-cut boreal landscape. Canadian Journal of Forest Resources 31:1805-1815.

Cotton, C.L. 1999. Winter habitat use and activity patterns of northern flying squirrels in subboreal forests. Thesis, University of Northern British Columbia, Prince George, British Columbia, Canada. , and K.L. Parker. 2000. Winter habitat and nest trees used by northern flying squirrels in subboreal forests. Journal of Mammalogy 81(4):1071-1086.

Cowan, I. M. 1936. Nesting habits of the flying squirrel Glaucomys volans. Journal of Mammalogy 59:886.

Dowdy, S. and S. Wearden. 1991. Statistics for Research. Second edition. John Wiley and Sons, New York City, New York, USA.

ESRI. 1994. GRID Commands Manual. ESRI, Redlands, California, USA.

Fies, M.L. and J.F. Pagels. 1991. Northern flying squirrel, G. s. fuscus Miller. Pages 583-584 in K. Terwilliger, editor. Virginia's endangered species. McDonald and Woodward Publishing Company, Blacksburg, Virginia, USA.

Gerrow, J.S. 1996. Homerange, habitat use, nesting ecology and diet of the northern flying squirrel in southern New Brunswick. Thesis. Acadia University, Wolfville, Nova Scotia, Canada. 
Hackett, H.M. and J.F. Pagels. 2003. Nest site characteristics of the endangered northern flying squirrel (Glaucomys sabrinus coloratus) in southwest Virginia. American Midland Naturalist 150:321-331.

Hamilton, W.J. 1943. The mammals of eastern United States. Comstock Publishing Company, Ithaca, New York, USA.

Hayward, G.D. and R. Rosentreter. 1994. Lichens as nesting material for northern flying squirrels in the northern Rocky Mountains. Journal of Mammalogy 75(3):663-673.

Hooge, P. N. and B. Eichenlaub. 1997. Animal movement extension to Arcview. Ver. 1.1. Alaska Science Center - Biological Science Office, U.S. Geological Survey, Anchorage, Alaska, USA.

Hurst, T.E. and M.J. Lacki. 1999. Roost selection, population size, and habitat use by a colony of Rafinesque's big-eared bats (Corynorhinus rafinesquii). American Midland Naturalist 142:363-371.

Kie, J., J.A. Baldwin, and C.J. Evans. 1996. CALHOME: a program for estimating animal home ranges. Wildlife Society Bulletin 24:342-344.

Loeb, S.C., F.H. Tainter, and E. Cázares. 2000. Habitat associations of hypogeous fungi in the Central Appalachians: Implications for the endangered northern flying squirrel (Glaucomys sabrinus coloratus). American Midland Naturalist 144:286-296.

Martin, K.J. and R.G. Anthony. 1999. Movements of northern flying squirrels in different-aged forest stands of western Oregon. Journal of Wildlife Management 63:291-297.

McDonald, L. 1995. Relationships between northern flying squirrels and stand age and structure in aspen mixedwood forests in Alberta. Pages 227-231 in: Relationships between stand age, stand structure, and biodiversity in aspen mixedwood forests in Alberta. J.B. Stelfox, 
editor. Alberta Environmental Centre, Vegreville, Alberta, and Canadian Forest Service (Project 0001A) Edmonton, Alberta, Canada.

Menzel, J.M. 2003. An examination of the habitat requirements of the endangered Virginia northern flying squirrel (Glaucomys sabrinus fuscus) by assessing nesting sites, habitat use, and the development of a habitat model. Dissertation, West Virginia University, Morgantown, West Virginia, USA.

, W.M. Ford, J.W. Edwards, and M.A. Menzel. 2004. Nest tree use by the endangered Virginia northern flying squirrel in the central Appalachian mountains. American Midland Naturalist 151:355-368.

Mitchell, D. 2001. Spring and fall diet of the endangered West Virginia northern flying squirrel (Glaucomys sabrinus fuscus). American Midland Naturalist 146:439-443.

Mowrey, R.A. and J.C. Zasada. 1984. Den tree use and movements of northern flying squirrels in interior Alaska and implications for forest management. Pages 351-356. in: W.R. Meehan, T.R. Merrell, Jr. and T.A. Hanley, editors. Fish and wildlife relationships in old growth forests: proceedings of a symposium. Bookmasters, Ashland, Ohio, USA.

Odom, R.H., W.M. Ford, J.W. Edwards, C.W. Stihler, and J.M. Menzel. 2001. Developing a habitat model for the endangered Virginia northern flying squirrel (Glaucomys sabrinus fuscus) in the Allegheny Mountains of West Virginia. Biological Conservation 99:245252.

Payne, J.L. 1983. Habitat variation among montane island populations of the flying squirrel, Glaucomys sabrinus in the Central Appalachian Mountains. Thesis, Virginia Commonwealth University, Richmond, Virginia, USA. 
, D.R. Young, and J.F. Pagels. 1989. Plant community characteristics associated with the endangered northern flying squirrel, Glaucomys sabrinus, in the Central Appalachians. American Midland Naturalist 121:285-292.

Rosenberg, D.K. 1990. Characteristics of northern flying squirrel and Townsend's chipmunk populations in second- and old-growth forests. Thesis, Oregon State University, Corvallis, Oregon, USA.

Smith, D.M. 1986. The practice of silviculture. John Wiley and Sons, New York City, New York, USA.

Stephenson, S.L. 1993. Upland Forests of West Virginia. McClain Printing, Parsons, West Virginia, USA.

Stihler, C., J. Wallace, M. Edwin, and H. Pawelczyk. 1995. Range of Glaucomys sabrinus fuscus, a federally endangered subspecies of the northern flying squirrel in West Virginia. Proceedings of the West Virginia Academy of Science 67:13-20.

Urban, V.K. 1988. Homerange, utilization, and activity of the endangered northern flying squirrel. Thesis, West Virginia University, Morgantown, West Virginia, USA.

U.S. Fish and Wildlife Service. 1990. Appalachian Northern Flying Squirrels (Glaucomys sabrinus fuscus and Glaucomys sabrinus coloratus) Recovery Plan. Newton Corner, Massachusetts, USA. .2001. Appalachian Northern Flying Squirrels (Glaucomys sabrinus fuscus and Glaucomys sabrinus coloratus) Updated Recovery Plan. Newton Corner, Massachusetts, USA.

Walker, E.P, F. Warnick, K.I. Lange, H.E. Uible, S.E. Hamlet, M.A. Davis, and P.F. Wright. 1964. Mammals of the world. Johns Hopkins Press, Baltimore, Maryland, USA. 
Webster, W.D., J.F. Parnell, and W.C. Biggs, Jr. 1985. Mammals of the Carolinas, Virginia, and Maryland. The University of North Carolina Press, Chapel Hill, North Carolina, USA.

Weigl, P.D., 1975. Parasitism as a possible biological weapon affecting the ranges and interactions of the flying squirrels, Glaucomys volans and G. sabrinus. Abstract of paper presented at $55^{\text {th }}$ Annual Meeting, American Society of Mammalogists, University of Montana.

1978. Resource overlap, interspecific interactions and the distribution of the flying squirrels, Glaucomys volans and G. sabrinus. American Midland Naturalist 100(1):83-96. and D.W. Osgood. 1974. Study of the northern flying squirrel, Glaucomys sabrinus, by temperature telemetry. American Midland Naturalist 92:484-486.

, T.W. Knowles, and A.C. Boynton. 1999. The distribution and ecology of the northern flying squirrel, Glaucomys sabrinus coloratus, in the Central Appalachians. North Carolina Wildlife Resources Commission, Raleigh, North Carolina, USA. , R.S. Hughes, and D.C. Battle. 2002. Study of northern flying squirrel populations along the Cherohala Skyway: questions of fragmentation and ecology in the southernmost part of the range. Division of Highways Report.

Wells-Gosling, N. and L.R. Heaney. 1984. Glaucomys sabrinus. Mammalian Species No.229:18.

Wenger, K.F. 1984. Forestry Handbook. John Wiley and Sons, New York City, New York, USA.

White, R.A. and G.C. Garrott. 1990. Analysis of wildlife radio-tracking data. Academic Press, New York, New York, USA. 
White, P.S., E.R. Buckner, J.D. Pittillo, and C.V. Cogbill. 1993. High-elevation forests: Sprucefir forests, northern hardwoods forests, and associated communities. Pages 305-337. in: W.H. Martin, S.G. Boyce, and A.C. Echternacht, editors. Biodiversity of the southeastern United States: Upland terrestrial communities. John Wiley and Sons, New York, New York, USA.

Witt, J.W. 1992. Homerange and density estimates for the northern flying squirrel, Glaucomys sabrinus, in western Oregon. Journal of Mammalogy 73:921-929. 
Table 1. Nest sites ( $n=31)$ used by Glaucomys sabrinus fuscus $(n=4)$ during the summers of 2002 and 2003 in Randolph County, West Virginia.

\begin{tabular}{llcccccc}
\hline \multirow{2}{*}{ Individual } & Gender & Leaf & Cavity & Nest box & Unknown & Days tracked & Mean nights/nest \\
\hline 097B & Female & 3 & 7 & 2 & 0 & 24 & 2.00 \\
WV344 & Female & 0 & 0 & 2 & 0 & 2 & 1.00 \\
280A & Male & 2 & 1 & 1 & 0 & 2.75 \\
$076 \mathrm{~B}$ & Male & 3 & 8 & 1 & 1 & 27 & 2.38 \\
\hline
\end{tabular}

${ }^{1}$ Individual was a nursing female who was preyed upon shortly after her capture 
Table 2. Comparison of 18 characteristics between nest trees $(n=29)$ used by Glaucomys sabrinus fuscus $(n=4)$ and random trees $(n$ =31) during the summers of 2002 and 2003 in Randolph County, West Virginia.

\begin{tabular}{|c|c|c|c|c|c|}
\hline \multirow[b]{2}{*}{ Variable } & \multicolumn{2}{|c|}{ Nest tree } & \multicolumn{2}{|c|}{ Random tree } & \multirow[b]{2}{*}{$P^{\mathrm{a}}$} \\
\hline & Mean & $\mathrm{SE}$ & Mean & $\mathrm{SE}$ & \\
\hline Elevation (m) & 1087.3 & 5.89 & 1086.6 & 5.98 & 0.705 \\
\hline Slope $(\%)$ & 11.6 & 0.02 & 10.8 & 0.02 & 0.301 \\
\hline Nest tree height (m) & 15.0 & 1.45 & 12.7 & 1.62 & 0.065 \\
\hline Nest tree DBH $(\mathrm{cm})$ & 26.9 & 1.96 & 22.6 & 1.71 & 0.067 \\
\hline Distance to nearest overstory tree $(\mathrm{m})$ & 2.3 & 0.33 & 2.4 & 0.27 & 0.973 \\
\hline Distance to nearest understory tree $(\mathrm{m})$ & 1.1 & 0.12 & 1.2 & 0.15 & 0.559 \\
\hline Number of overstory trees & 13.7 & 1.11 & 14.5 & 1.10 & 0.515 \\
\hline Overstory basal area $\left(\mathrm{m}^{2} / \mathrm{ha}\right)$ & 2.0 & 0.20 & 2.1 & 0.21 & 0.777 \\
\hline Overstory mean height (m) & 22.7 & 0.87 & 22.3 & 0.95 & 0.867 \\
\hline Number of snags & 9.2 & 1.18 & 9.5 & 1.19 & 0.845 \\
\hline Snag basal area $\left(\mathrm{m}^{2} / \mathrm{ha}\right)$ & 0.2 & 0.03 & 0.1 & 0.02 & 0.343 \\
\hline
\end{tabular}


Table 2. cont.

\begin{tabular}{|c|c|c|c|c|c|}
\hline \multirow[b]{2}{*}{ Variable } & \multicolumn{2}{|c|}{ Nest tree } & \multicolumn{2}{|c|}{ Random tree } & \multirow[b]{2}{*}{$P^{\mathrm{a}}$} \\
\hline & Mean & $\mathrm{SE}$ & Mean & $\mathrm{SE}$ & \\
\hline Average height of snags (m) & 6.2 & 0.44 & 6.7 & 0.60 & 0.374 \\
\hline Canopy closure (\%) & 66.9 & 3.73 & 65.3 & 3.48 & 0.715 \\
\hline Midstory cover & 55.3 & 4.45 & 57.6 & 3.92 & 0.645 \\
\hline Seedling cover & 10.4 & 1.65 & 12.9 & 2.80 & 0.323 \\
\hline Forest floor vegetation & 34.1 & 4.47 & 49.4 & 5.82 & 0.062 \\
\hline Moss cover & 9.7 & 2.02 & 7.4 & 1.26 & 0.376 \\
\hline Rock cover & 1.8 & 1.17 & 1.6 & 0.81 & 0.922 \\
\hline
\end{tabular}

${ }^{\mathrm{a}}$ Paired $t$-test 
Table 3. Component loadings for principal component analysis of the characteristics of nest trees used by Glaucomys sabrinus fuscus during the summers of 2002 and 2003 in Randolph County, West Virginia.

\begin{tabular}{|c|c|c|}
\hline Variable & PC1 & PC2 \\
\hline Elevation (m) & 0.7305 & -0.1905 \\
\hline Slope $(\%)$ & -0.6838 & -0.2794 \\
\hline Nest tree height $(\mathrm{m})$ & -0.1030 & 0.7947 \\
\hline Nest tree DBH $(\mathrm{cm})$ & -0.4801 & 0.6436 \\
\hline Distance to nearest overstory tree (m) & 0.0600 & 0.6606 \\
\hline Distance to nearest understory tree $(\mathrm{m})$ & 0.2024 & 0.1419 \\
\hline Number of overstory trees & 0.8804 & 0.1333 \\
\hline Overstory basal area $\left(\mathrm{m}^{2} / \mathrm{ha}\right)$ & 0.7233 & 0.0600 \\
\hline Overstory mean height (m) & -0.7949 & -0.1251 \\
\hline Number of snags & 0.8316 & -0.1578 \\
\hline Snag basal area $\left(\mathrm{m}^{2} / \mathrm{ha}\right)$ & 0.6661 & -0.0628 \\
\hline Average height of snags (m) & -0.1864 & 0.2750 \\
\hline Canopy closure (\%) & -0.2571 & -0.2075 \\
\hline Midstory cover & -0.3053 & -0.5629 \\
\hline Seedling cover & 0.2686 & -0.3296 \\
\hline Forest floor vegetation & -0.3540 & 0.3932 \\
\hline Moss cover & 0.2717 & 0.2927 \\
\hline Rock cover & -0.4819 & -0.3273 \\
\hline Eigenvalues & 5.0 & 2.6 \\
\hline Variance explained (\%) & 28.1 & 14.3 \\
\hline
\end{tabular}


Table 4. Homerange size of Glaucomys sabrinus fuscus during the summers of 2002 and 2003 in Randolph County, West Virginia.

\begin{tabular}{|c|c|c|c|c|c|}
\hline & & & Adaptive & nethod (he & \\
\hline Individual & Gender & Locations & $95 \% \mathrm{CI}^{1}$ & $50 \% \mathrm{CI}$ & $\mathrm{MCP}^{2}$ (ha) \\
\hline 076B & Male & 82 & 24.7 & 5.0 & 29.5 \\
\hline 097B & Female & 64 & 3.4 & 0.3 & 2.9 \\
\hline
\end{tabular}

${ }^{1}$ Contour interval

${ }^{2}$ Minimum convex polygon 
Table 5. Glaucomys sabrinus fuscus habitat use at the local scale (within the homerange) during the summers of 2002 and 2003 in Randolph County, West Virginia as calculated with euclidian distance.

\begin{tabular}{|c|c|c|c|c|}
\hline Individual & Year & Cover type & Mean ${ }^{a}$ & $P$ \\
\hline \multirow[t]{5}{*}{ 076B } & 2003 & Clearcut & 0.95 & 0.403 \\
\hline & & Mixed forest & 10.09 & 0.095 \\
\hline & & Deciduous forest & 1.05 & 0.032 \\
\hline & & Grassy edge & 0.80 & 0.030 \\
\hline & & Stream & 0.71 & 0.001 \\
\hline \multirow[t]{4}{*}{ 097B } & 2002 & Mixed forest & 0.09 & 0.353 \\
\hline & & Deciduous forest & 0.82 & 0.477 \\
\hline & & Grassy edge & 0.68 & 0.455 \\
\hline & & Stream & 0.96 & 0.231 \\
\hline
\end{tabular}

${ }^{\text {a }}$ Ratio of mean distance from used locations to mean distance from randomly selected locations 
Table 6. Habitat use at the stand and landscape scales for Glaucomys sabrinus fuscus during the summers of 2002 and 2003 in Randolph County, West Virginia. Ratios were calculated by dividing the known proportion of each cover type used by the availability at each scale.

\begin{tabular}{|c|c|c|c|c|c|c|}
\hline \multirow[b]{2}{*}{ Individual } & \multirow[b]{2}{*}{ Cover type } & \multirow[b]{2}{*}{ Proportion used } & \multicolumn{2}{|c|}{ Proportion available } & \multicolumn{2}{|c|}{ Ratio } \\
\hline & & & Stand & $\overline{\text { Landscape }}$ & Stand & Landscape \\
\hline \multirow[t]{5}{*}{$076 \mathrm{~B}$} & Clearcut & 0.00 & 0.01 & 0.05 & & \\
\hline & Mixed forest & 0.87 & 0.71 & 0.50 & 1.2 & 1.8 \\
\hline & Deciduous forest & 0.00 & 0.27 & 0.44 & & \\
\hline & Grassy edge & 0.13 & 0.01 & 0.01 & 21.3 & 9.8 \\
\hline & Water & 0.00 & 0.00 & 0.00 & & \\
\hline \multirow[t]{5}{*}{ 097B } & Clearcut & 0.00 & 0.00 & 0.05 & & \\
\hline & Mixed forest & 0.85 & 0.17 & 0.50 & 5.1 & 1.7 \\
\hline & Deciduous forest & 0.03 & 0.81 & 0.44 & 0.04 & 0.1 \\
\hline & Grassy edge & 0.12 & 0.02 & 0.01 & 5.2 & 9.2 \\
\hline & Water $^{1}$ & 0.00 & 0.001 & 0.00 & & \\
\hline
\end{tabular}

\footnotetext{
${ }^{1}$ Although there was no standing water on the study site, the stand scale for 097B included standing water on the adjacent property.
} 


\section{FIGURE LEGEND}

Figure 1. Location of MeadWestvaco Wildlife Ecosystem Research Forest (MWERF) and Kumbrabow State Forest (KSF) in Randolph County, West Virginia.

Figure 2. Proportion of nest tree species used by West Virginia northern flying squirrels for leaf and cavity nests $(n=25)$ compared with abundance of tree species $(n=398)$ in the overstory during the summers of 2002 and 2003 on Kumbrabow State Forest and the MeadWestvaco Wildlife and Ecological Research Forest in Randolph County, West Virginia. Asterisks indicate disproportionate $(P<0.05)$ use of the species.

Figure 3. Eigenvalue scores for principal component 1 and principal component 2 for random sites and nest trees used by 4 radio-collared West Virginia northern flying squirrels during the summers of 2002 and 2003 on Kumbrabow State Forest and the MeadWestvaco Wildlife and Ecological Research Forest in Randolph County, West Virginia.

Figure 4. Homerange of West Virginia northern flying squirrel 097B including individual locations as derived from known nest sites and estimated locations $(n=64)$, core area of use, and cover types used at Kumbrabow State Forest, Randolph County, West Virginia during the summer of 2002.

Figure 5. Homerange of West Virginia northern flying squirrel 076B including individual locations as derived from known nest sites and estimated locations $(n=82)$, core area of use, and cover types used on the MeadWestvaco Wildlife and Ecological Research Forest, Randolph County, West Virginia during the summer of 2003. 


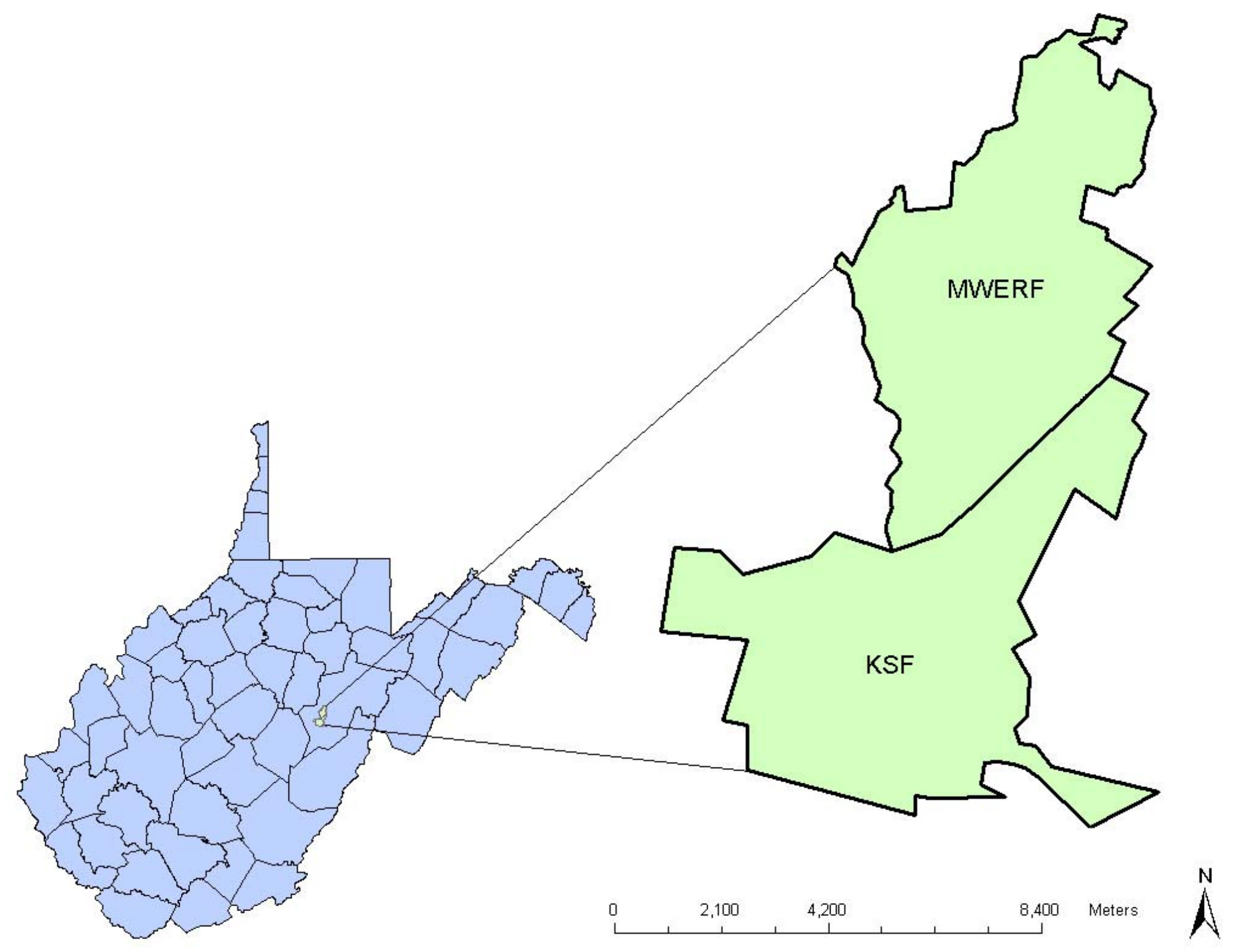




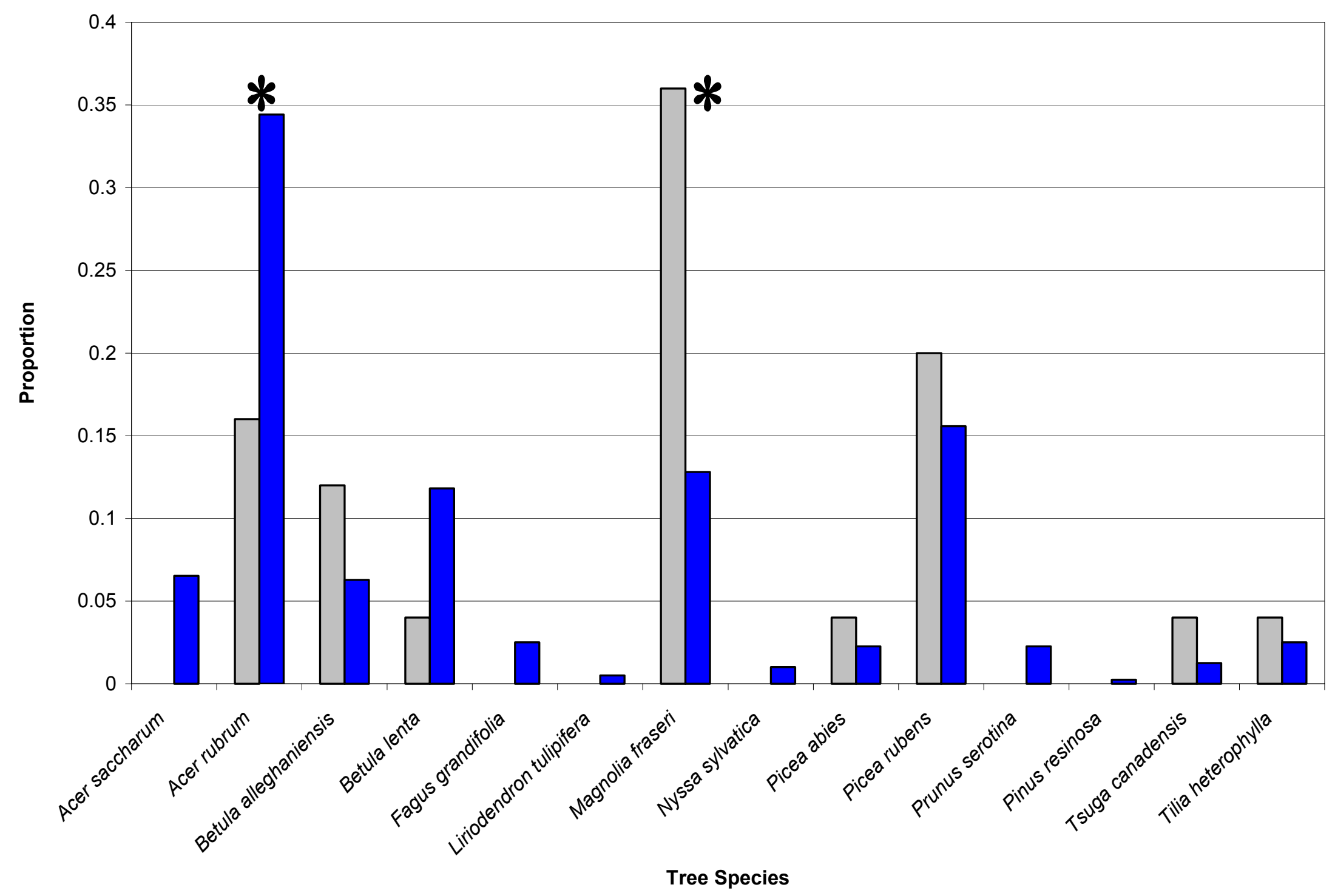

$\square$ Nest Trees $\square$ Available 


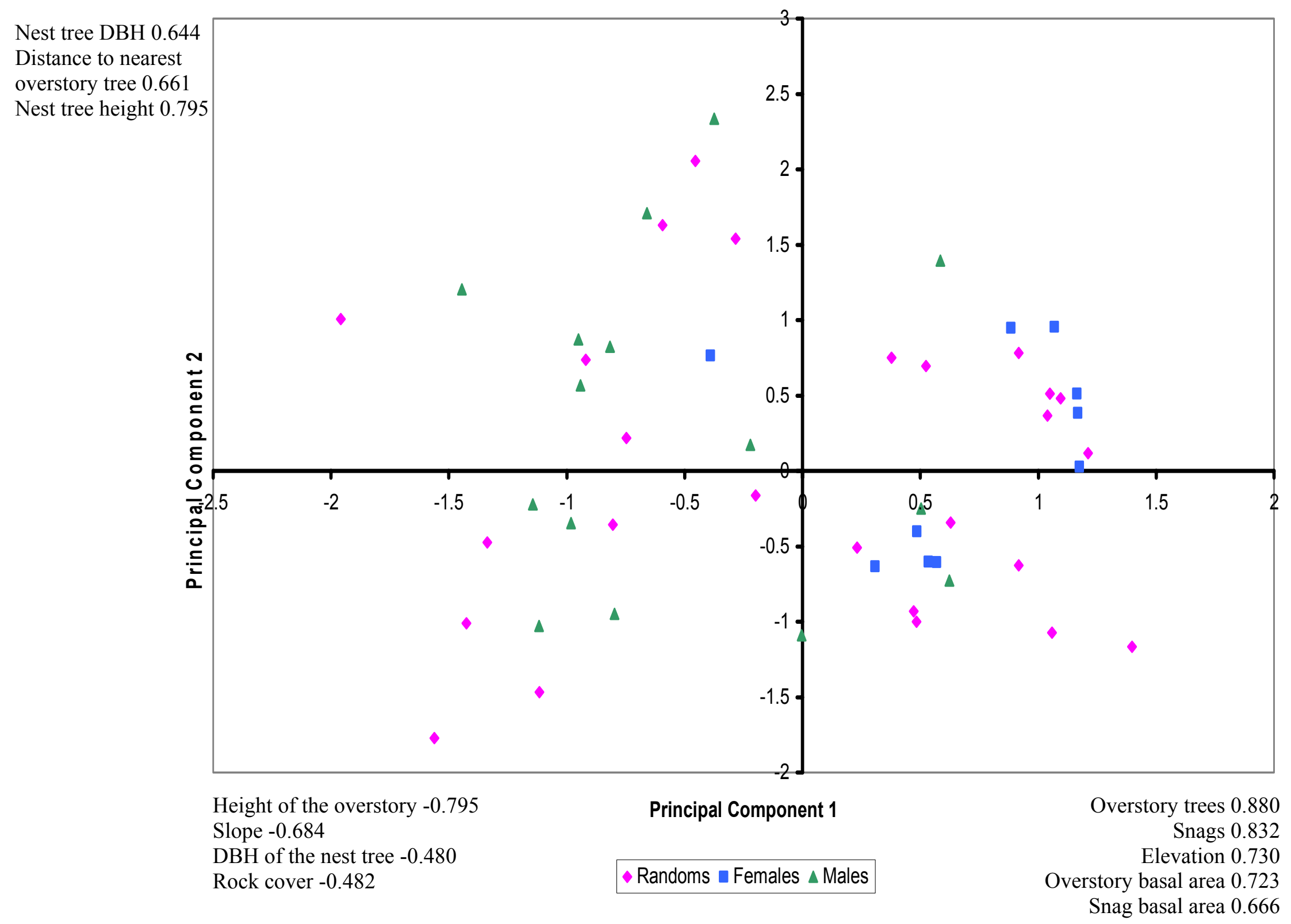




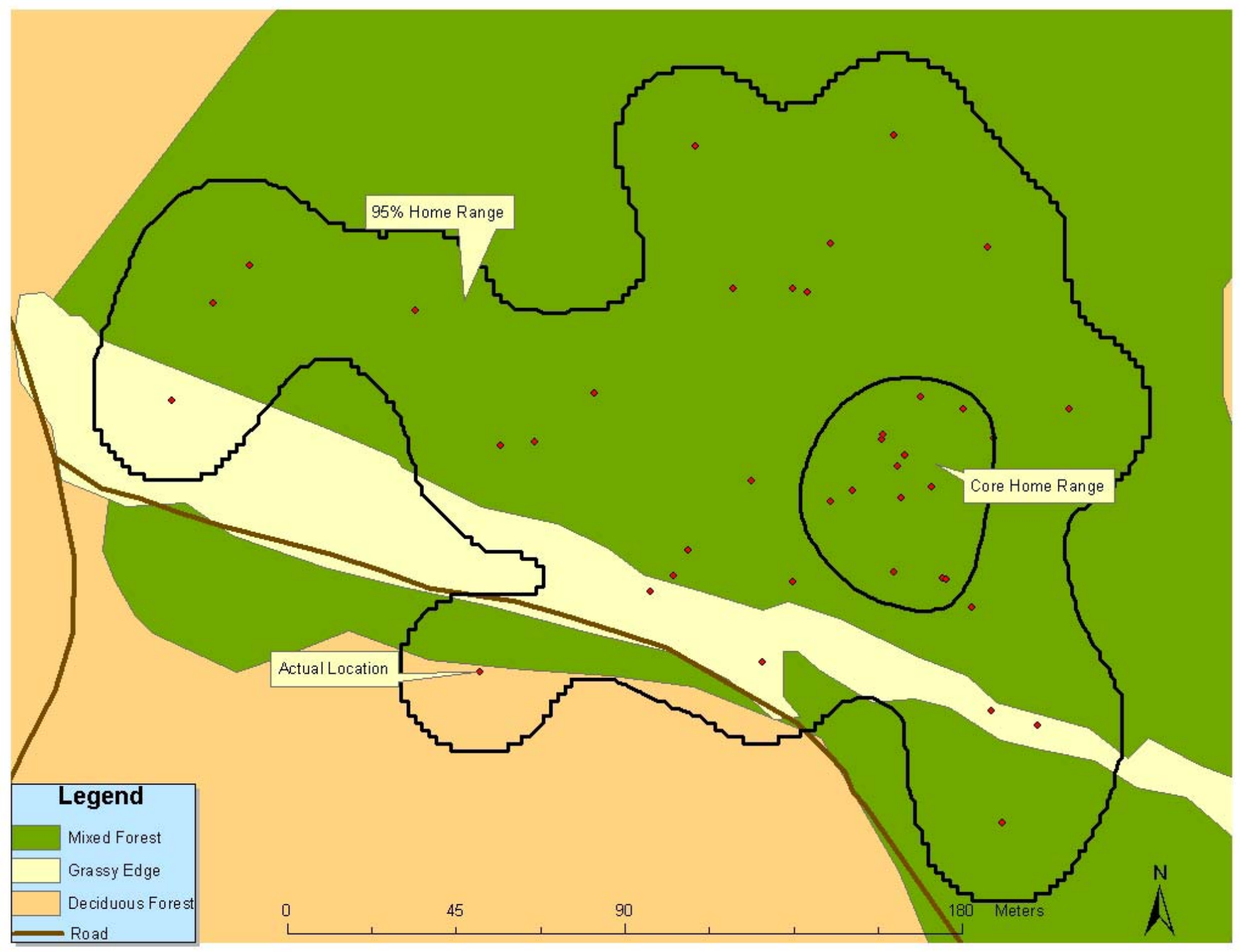




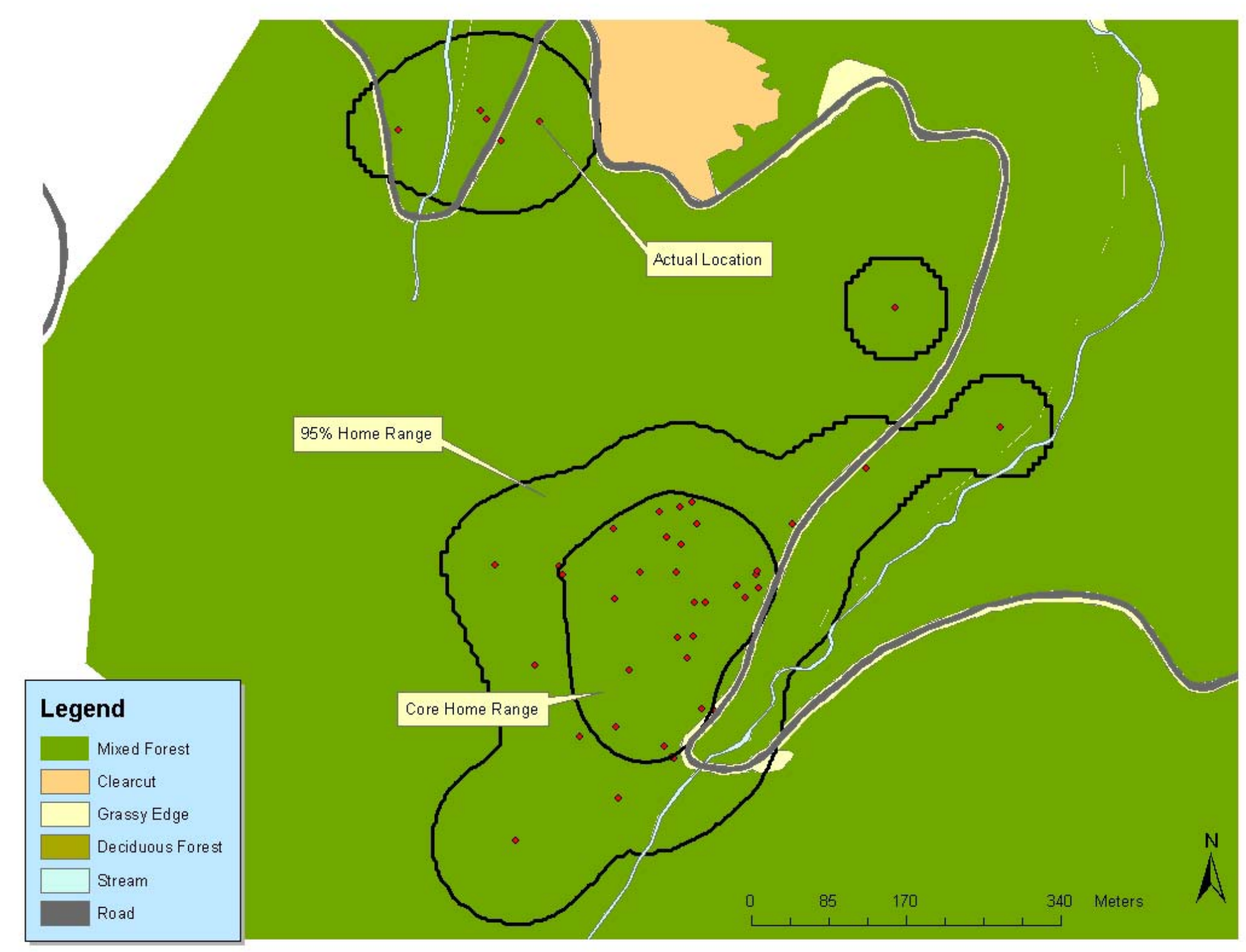


Appendix A. Trap arrangement of Tomahawk 201 and 202 live traps used to trap Glaucomys sabrinus fuscus at Kumbrabow State Forest during the summer of 2002. Traps were placed in 5 transects of 10 traps with not less than 5 and not more than $10 \mathrm{~m}$ between consecutive traps within the line. Each box represents one live trap.

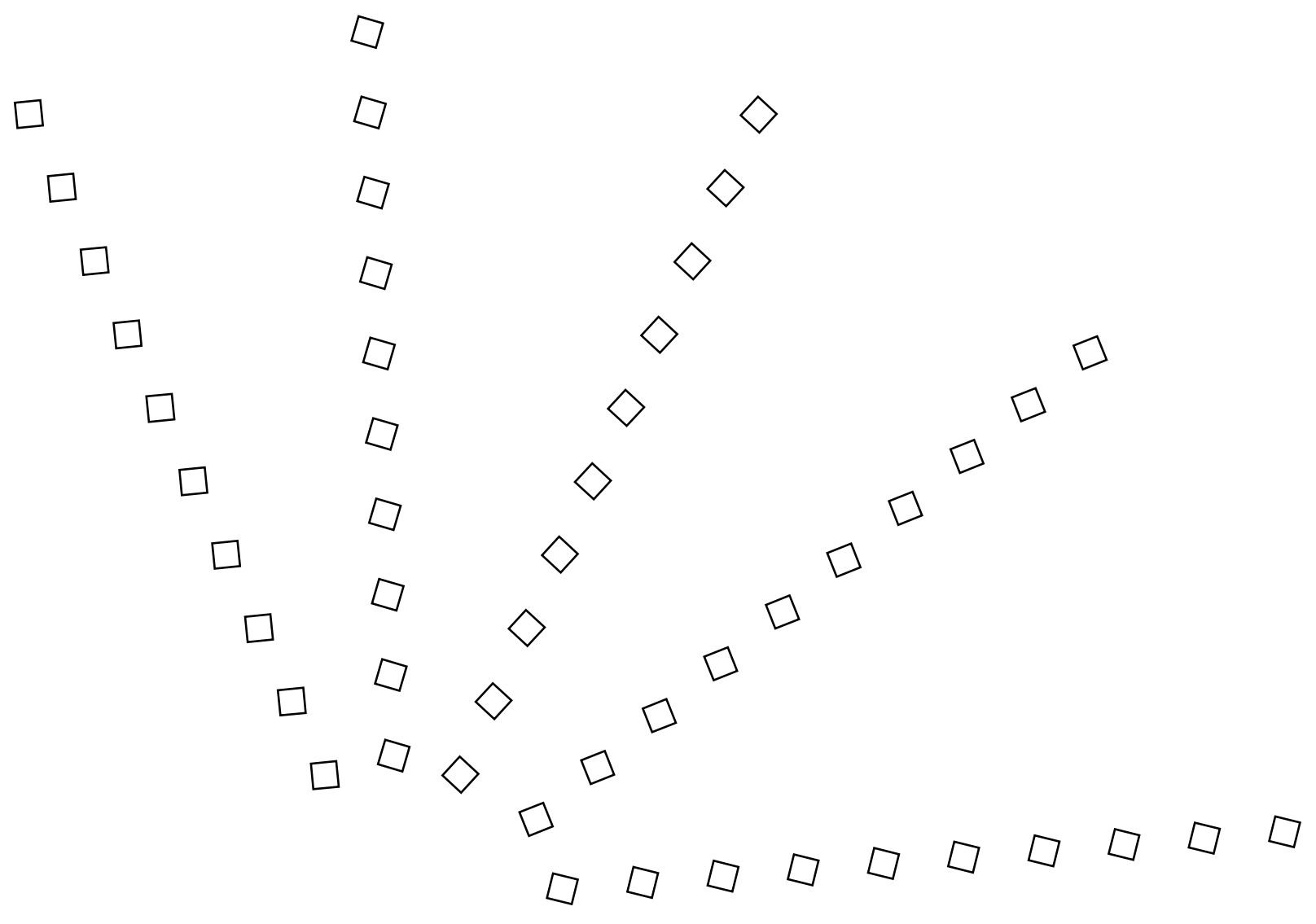


Appendix B. Trap arrangement of Tomahawk 201 and 202 live traps used to trap Glaucomys sabrinus fuscus at Kumbrabow State Forest during the summer of 2003. Traps were placed in two parallel transects with $50 \mathrm{~m}$ between consecutive traps. Transects were separated by $50 \mathrm{~m}$. Each box represents one live trap.

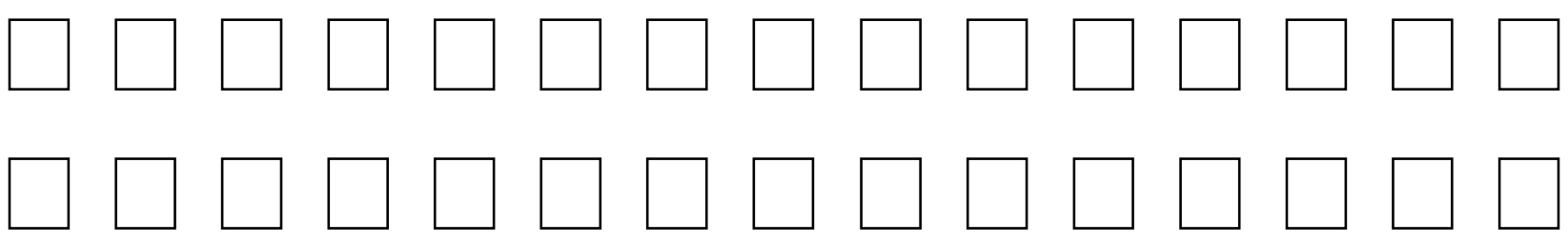


CHAPTER 2 - AN EXAMINATION OF NEST BOX OCCUPANCY BY GLAUCOMYS SABRINUS FUSCUS IN WEST VIRGINIA

\section{INTRODUCTION}

Artificial nests have been used successfully as supplemental nest sites for many cavity nesting species. They have assisted in the recovery of declining populations of species such as wood duck (Aix sponsa), red-cockaded woodpecker (Picoides borealis), and leadbeater's possum (Gymnobelideus leadbeateri; Lowney 1989, Conner et al. 2002, Lindenmayer et al. 2003). Nest boxes have been used in the Pacific Northwest in an attempt to increase densities of the northern flying squirrel (Glaucomys sabrinus), which are a main prey item of the endangered spotted owl (Strix occidentalis; Carey 2002).

Wooden nest boxes have been erected not only to augment natural cavities, but also as a means to capture the endangered Appalachian subspecies of northern flying squirrel, the Carolina northern flying squirrel (G.s. coloratus) and West Virginia northern flying squirrel (G.s. fuscus; Weigl et al. 1999, Hackett and Pagels 2003). Although much effort is put forth in periodically checking these nest boxes for flying squirrel presence, they have consistently low occupancy rates. Nest boxes are widely used for these subspecies, but no studies have examined their use in West Virginia.

The objective of this study was to examine the efficacy and effectiveness of nest boxes to capture G.s. fuscus in West Virginia. Using historic nest box capture data, I developed a predictive nest box occupancy model based on habitat characteristics of the locations and compared nest box occupancy among G.s. fuscus presence classifications and seasons. 


\section{METHODS}

Since 1985, the West Virginia Division of Natural Resources has erected 663 nest boxes at 39 sites in or near montane forests in Greenbrier, Pendleton, Pocahontas, Randolph, Tucker, and Webster Counties. The forests typically are comprised of red spruce (Picea rubens), eastern hemlock (Tsuga canadensis), red maple (Acer rubrum), sugar maple (A. saccharum), yellow birch (Betula allegeniensis), American beech (Fagus grandifolia), Fraser magnolia (Magnolia fraseri), and black cherry (Prunus serotina; Stephenson 1993). Of the 663 nest boxes, global position system (GPS) coordinates have been obtained for 363 nest boxes at 21 sites . The nest boxes are constructed of cedar (Thuja spp.) and have inside dimensions of $33.3 \times 12.1 \times 12.5 \mathrm{~cm}$ with a $4.8 \mathrm{~cm}$ opening on either side. The nest boxes are hung $\geq 3 \mathrm{~m}$ off the ground on the boles of live trees. The nest boxes mostly are checked once or twice yearly. The presence of G.s. fuscus and number captured are recorded for each nest box check. An occupancy value was calculated for each of the nest boxes. This was defined as the proportion of checks for each nest box that had G.s. fuscus present.

Menzel (2003) used characteristics of known G.s. fuscus habitats to create a likelihood of presence model. Elevation and the presence or absence of spruce forest or spruce-hardwood forest were used to create a predictive logistic model equation corresponding to G.s fuscus presence. The resulting probabilities are classified as submarginal (0-49\%), marginal (50-75\%), or optimal $(76-100 \%)$.

\section{Predictive Model}

Each known nest box location was plotted and G.s. fuscus presence probability, elevation, the presence $($ vegetation $=1$ ) or absence $($ vegetation $=0$ ) of spruce or mixed spruce-hardwood forest, and aspect were recorded. All variables were put into a logistic model using a backward 
procedure to predict nest box occupancy. Nonsignificant variables were removed from the model. A significance level of 0.05 was used for all statistical tests. Vegetation, elevation, and aspect were obtained from GIS land coverages with 0.09 ha resolution. I randomly selected 181 of the 363 locations to create a logistic model and used the remaining 182 to test the model. The randomization of data and creation of the model was repeated 50 times. The resulting constants were averaged across the 50 iterations. The mean values were used in the logistic model.

\section{Differences Among G.s. fuscus Presence Probabilities}

I tested for differences in nest box occupancy across the G.s. fuscus probability classifications for the 363 nest boxes with recorded locations. Each nest box was considered used (1) or not used (0). I then used an ANOVA to test for differences among probability categories (submarginal, marginal, optimal); pairwise contrasts were used to determine the sources of the differences.

\section{Differences Among Seasons}

I used nest box check records for all 663 nest boxes to test for differences in G.s. fuscus occupancy and numbers of flying squirrels captured among seasons. Checks were categorized as winter (December - February), spring (March - May), summer (June - August) or fall (September - November). For each nest box check, G.s. fuscus presence was recorded as a 0 (absent) or 1 (present). If G.s. fuscus was present, then the number of individuals in the nest box was recorded, otherwise the value was recorded as 0. I conducted an ANOVA and subsequent pairwise contrasts to test for differences in G.s. fuscus occupancy and number of squirrels captured among seasons. 


\section{RESULTS}

The 363 nest boxes with known locations were checked for G.s. fuscus occupancy 6,257 times between 1986 and 2003. Each of these boxes was checked between 3 and 41 times. These nest boxes resulted in 131 instances of G.s. fuscus occupancy totaling 307 flying squirrels, including repeat captures (e.g., an individual captured on two occasions was counted twice).

\section{Predictive Model}

All variables were used to create logistic models. The most significant model included presence probability, elevation, and vegetation. Aspect was not significant in any models. The resulting model after calculating the mean values for the constants was:

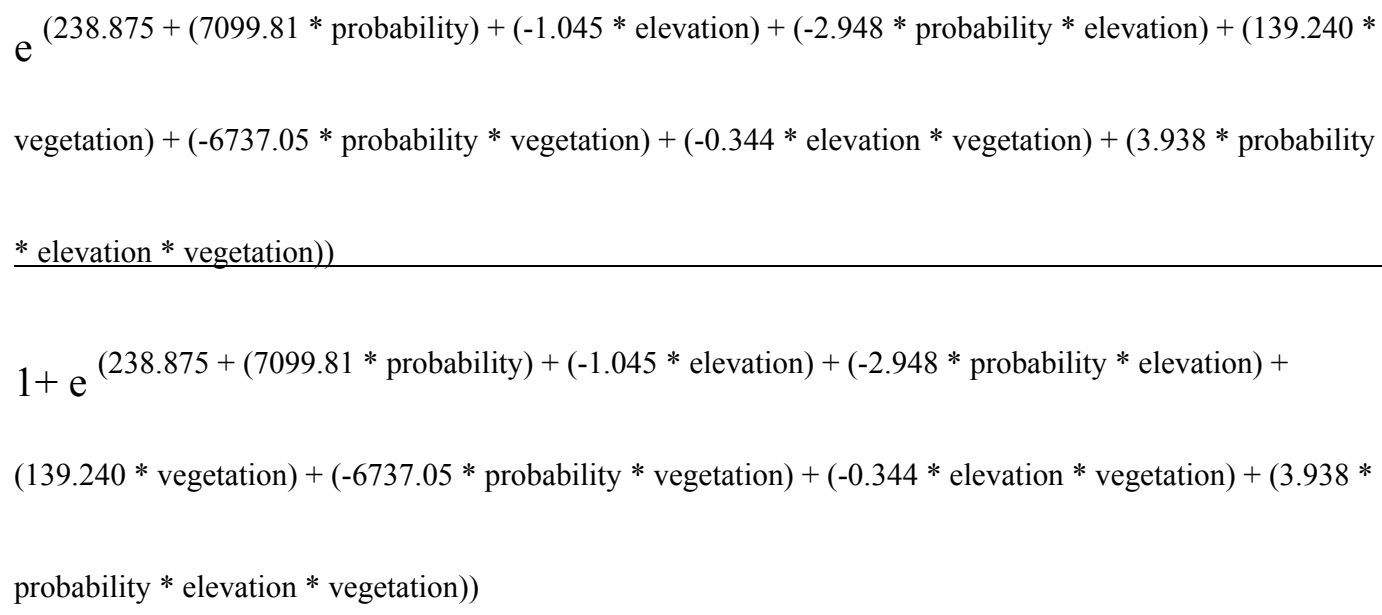

After 50 separate runs of the model, I compared the actual occupancy of the nest boxes to the occupancy predicted by the logistic model. The result was $r=0.119(P<0.001$, Fig. 1$)$. Using this model, only $1.4 \%$ of the variation in occupancy could be explained by northern flying squirrel presence probability, elevation, and vegetation. 


\section{Differences Among G.s. fuscus Presence Probabilities}

Nest box occupancy differed among the presence probability classifications $(P=0.002, \mathrm{~F}$ $=6.46$, Table 1$)$. Nest boxes in optimal sites had greater occupancy than both marginal $(P=$ $0.002, \mathrm{~F}=10.28)$ and submarginal $(P<0.001, \mathrm{~F}=7.2)$ sites.

\section{Differences Among Seasons}

The 663 nest boxes were checked 10,850 times between 1986 and 2003. These nest boxes had 171 instances of G.s. fuscus occupancy totaling 394 squirrels, including recaptures. G.s. fuscus occupancy varied among seasons $(N=171, P<0.001$, Table 2$)$, with spring and summer returning the highest G.s. fuscus occupancy. Nest box checks in spring $(P=0.002)$ and summer $(P=0.025)$ yielded more G.s. fuscus than in fall.

The numbers of G.s. fuscus found in the nest boxes differed among seasons $(N=394, P<$ 0.001, F = 5.69, Table 3). Spring and summer again had the highest numbers of G.s. fuscus. Both spring $(P<0.001, \mathrm{~F}=13.19)$ and summer $(P=0.028, \mathrm{~F}=3.76)$ had more G.s. fuscus captures than winter. Spring $(P=0.006, \mathrm{~F}=4.48)$ and summer $(P=0.027, \mathrm{~F}=3.87)$ also had higher G.s. fuscus numbers than fall.

\section{DISCUSSION}

\section{Predictive model}

The probability of northern flying squirrel presence, elevation, and vegetation of the location of a nest box contribute little (1.4\%) to the occupancy of an individual nest box. Apparently, other environmental factors have a greater influence on the use of nest boxes. One possible explanation is low densities of G.s. fuscus, or their absence from some of the locations. However, recent evidence suggests that G.s. fuscus may not be limited by nest site availability 
(Chapter 1, Menzel et al. 2004), therefore reducing the need for natural cavities. Individual flying squirrels are known to use multiple nests (Chapter 1), so although they may be using nest boxes, they may not be present on the particular date the boxes are checked. This is evidenced by the common occurrence of nest material and flying squirrel fur and scat in nest boxes. It is likely that with more nest box checks individuals that occasionally use nest boxes could be captured.

Other species, such as Peromyscus spp. and red squirrels (Tamiasciurus hudsonicus), commonly are found using nest boxes. Red squirrels often enlarge the entrance of G.s. fuscus nest boxes. Once the entrance is enlarged, flying squirrels may avoid these boxes because of increased exposure to the elements and use by red squirrels. Stone et al. (1996) reported that southern flying squirrels ( $G$. volans) in Arkansas preferred nest boxes with smaller $(3.8 \mathrm{~cm})$ entrances over larger $(6.4 \mathrm{~cm})$ ones. A simple method for discouraging red squirrels from enlarging the hole is to surround the entrance with sheet metal or wire screen. This method currently is not being used for G.s. fuscus boxes in West Virginia.

The low occupancy of nest boxes may be explained by the nest boxes themselves. A nest box may take longer than a natural cavity to become a suitable nest site. There could be a period of time that the nest box needs to age and weather before a G.s. fuscus chooses to use it as a cavity. This is evidenced by the fact that none of the nest boxes had northern flying squirrel captures within the first year. However, similar nest box programs conducted elsewhere have seen Sciurid use of nest boxes shortly after their placement. Eurasian red squirrels (Sciurus vulgaris) began using nest boxes in Great Britain within three months (Shuttleworth 1999). Moreover, Sawyer (1983) found 9 southern flying squirrels using 2 nest boxes 17 days after placing them in Virginia. However, G.s. fuscus in the current study is believed to be at a lower 
density than the southern flying squirrels in Sawyer's (1983) study. Competition for nest sites could influence the search for and attractiveness of artificial cavities.

Natural cavities may be selected for because of remnant matter from cavity excavation that can be incorporated into nest material. Newly hung nest boxes are devoid of nest material. Perhaps their use could be expedited by adding nest material such as excelsior or shredded bark to a nest box when it is hung.

Further research is needed to identify the factors that affect the variation in nest box occupancy for G.s. fuscus in West Virginia. Using the nest box location's presence probability, elevation, and vegetation is merely a first step in identifying why some boxes yield more northern flying squirrels than others. It is possible that factors such as snag basal area, overstory height, volume of coarse woody debris, or availability of hypogeous fungi may help further explain the variance in nest box occupancy.

\section{Differences Among G.s. fuscus Presence Probabilities}

G.s. fuscus presence probability appears to affect the occupancy of nest boxes. Nest boxes on marginal and submarginal sites were less likely to be used than those on optimal sites. Although optimal sites often are characterized by an abundance of potential nest sites, both interand intraspecific competition for nests may facilitate a greater occupancy of artificial nests. Perhaps where G.s. fuscus inhabits these sites, population densities are low in marginal and submarginal sites and, therefore, they are faced with an abundance of natural nest sites. A likely cause for the low occupancy in the submarginal and marginal areas is a low and fluctuating density of G.s. fuscus at the sites. These sites tend to be characterized by more hardwood dominated forest than the optimal sites. Southern flying squirrels often occupy sites with overstory hard mast producing trees (Dolan 1977). A captive study suggests than in areas of 
sympatry, southern flying squirrels may outcompete northern flying squirrels for nest sites, and even displace northern flying squirrels from established nests (Weigl 1978). Competition with the southern flying squirrel could negatively affect northern flying squirrel nesting and population success in these areas. However, there are sites in West Virginia where both species are known to have cohabitated for several decades (C.W. Stihler, WVDNR, personal communication).

\section{Differences Among Seasons}

The season in which nest boxes are checked may affect nest box occupancy. This variation must be taken into consideration when using nest boxes to determine G.s. fuscus presence. By examining the differences in captures among seasons, researchers can adjust their efforts to maximize their likelihood of capturing G.s. fuscus and identify new populations.

Despite known increased winter use by southern flying squirrels (Sawyer 1983, Hatten and Nelson 1992), G.s. fuscus is not known to use nest boxes in the winter. G.s. coloratus, however, has been found using nest boxes during the winter (C. McGrath, North Carolina Wildlife Resources Commission, personal communication). The lack of use by G.s. fuscus could be an indication as to the nest boxes' ability to shelter flying squirrels from harsh winter conditions. Naturally occurring nests may have thermal characteristics that make them more appealing than nest boxes. Although winter aggregations of G.s. fuscus are unknown, multiple flying squirrels could be sharing nests, but are doing so in natural cavities and not nest boxes. The lack of known winter use could be the result of few nest box checks. Nest boxes in West Virginia have only been checked during the winter months on 325 occasions. These checks include 183 different nest boxes that resulted in no captures. If more effort was concentrated on nest box checks during the winter, then G.s. fuscus use of nest boxes during this season may be 
documented. The harsh winter weather conditions of the sites where these nest boxes are located makes monitoring them during this season very difficult, if not impossible.

Although they comprise $44.0 \%$ of the nest box checks, $26.3 \%$ of the captures, and $24.6 \%$ of G.s. fuscus captured, fall nest box checks are less successful than summer checks. Spring yielded not only the highest rate of captures, but also the most flying squirrels. Spring also had higher occupancy and more G.s. fuscus captured than fall. Spring and summer likely yield the greatest numbers of flying squirrels captured because nest boxes are being used for rearing young or mating. The frequent low temperatures in fall may make natural cavities more appealing nest sites than nest boxes. The data suggests that more G.s. fuscus could be captured in nest boxes by concentrating efforts in spring and summer instead of spring and fall.

Unfortunately, time constraints make it difficult for the Division of Natural Resources to conduct summer nest box checks. The majority of the summer nest box checks were done at one particular site in order to prove northern flying squirrel presence. Given this origin of most of the nest box checks, I suggest that by concentrating the effort in the seasons with the greatest occupancy, researchers could gain a greater understanding of the G.s. fuscus population, its health, and distribution.

\section{MANAGEMENT IMPLICATIONS}

Although widely accepted as a useful means of capturing G.s. fuscus in West Virginia, nest boxes seldom result in captures. Their continued use as a means to capture G.s. fuscus and determine its presence may ultimately result in loss of valuable habitat. Although an established flying squirrel population may exist at a site, a series of nest boxes may not result in a capture. This information could lead to the erroneous assumption of flying squirrel absence and subsequent mismanagement of the site that could harm the population. The low occupancy of 
nest boxes may underestimate the range of the population when the nest boxes are used to determine flying squirrel presence or absence. Live traps may be a more effective means of capturing G.s. fuscus, but live trapping also has an extremely low capture success (Chapter 1, Menzel et al. 2003).

The overall effectiveness of nest boxes could be improved in West Virginia with periodic checks concentrated during spring and summer, when the occupancy rate is highest. Little is known of G.s. fuscus nest selection and habitat use during winter. An increased effort during these months likely would result in G.s. fuscus. These individuals then could be studied to learn about winter requirements of the species. Ultimately, researchers need to understand better the overall requirements of G.s. fuscus during all seasons to manage properly for the remaining populations. It is through an increased knowledge of the species and its requirements and implementation of recover actions consistent withthese needs that researchers will be able to recover populations and see G.s. fuscus's removal from the Endangered Species List.

\section{LITERATURE CITED}

Carey, A.B. 2002. Response of northern flying squirrels to supplementary dens. Wildlife Society Bulletin 30(2):547-556.

Conner, R.N., D. Saens, D.C. Rudolph, and R. R. Schaefer. 2002. Does the availability of artificial cavities affect cavity excavation rates in red-cockaded woodpeckers? Journal of Field Ornithology 73(2): 125-129.

Dolan, P.G. and D.C. Carter. 1977. Glaucomys volans. Mammalian Species. 78:1-6.

Hackett, H.M. and J.F. Pagels. 2003. Nest site characteristics of the endangered northern flying squirrel (Glaucomys sabrinus coloratus) in southwest Virginia. American Midland Naturalist 150:321-331. 
Hatten, S. and D. Nelson. 1992. Nest box use by southern flying squirrels (Glaucomys volans) in Alabama. Abstract in Alabama Academy of Science Journal p.66

Lindenmayer, D.B., C.I. MacGregor, R.B. Cunningham, R.D. Incoll, M. Crane, D. Rawlins, D.R. Michael. 2003. The use of nest boxes by arboreal marsupials in the forests of the central Highlands of Victoria. Wildlife Research 30(3):259-264.

Lowney, M.S. 1989. Wood duck nest sites in bottomland hardwood forests of Mississippi. Journal of Wildlife Management 53(2):378-382.

Menzel, J.M. 2003. An examination of the habitat requirements of the endangered Virginia northern flying squirrel (Glaucomys sabrinus fuscus) by assessing nesting sites, habitat use, and the development of a habitat model. Dissertation, West Virginia University, Morgantown, West Virginia, USA.

, W.M. Ford, J.W. Edwards, and M.A. Menzel. 2004. Nest tree use by the endangered Virginia northern flying squirrel in the central Appalachian mountains. American Midland Naturalist 151:355-368.

Sawyer, S.L. 1983. Homing and ecology in the southern flying squirrel, Glaucomys volans, in southeastern Virginia. Thesis, Old Dominion University, Norfolk, Virginia, USA.

Shuttleworth, C.M. 1999. The use of nest boxes by the red squirrel (Sciurus vulgaris) in a coniferous habitat. Mammal Review 29(1):61-66.

Stephenson, S.L. 1993. Upland Forests of West Virginia. McClain Printing, Parsons, West Virginia, USA.

Stone, K.D., G.A. Heidt, W.H. Baltosser, and P.T. Caster. 1996. Factors affecting nest box use by southern flying squirrels (Glaucomys volans) and gray squirrels (Sciurus carolinensis). American Midland Naturalist 135(1):9-13. 
Weigl, P.D., 1978. Resource overlap, interspecific interactions and the distribution of the flying squirrels, Glaucomys volans and G. sabrinus. American Midland Naturalist 100(1):83-96. , T.W. Knowles, and A.C. Boynton. 1999. The distribution and ecology of the northern flying squirrel, Glaucomys sabrinus coloratus, in the Central Appalachians. North Carolina Wildlife Resources Commission, Raleigh, North Carolina, USA. 
Table 1. Use of Glaucomys sabrinus fuscus nest boxes in West Virginia by presence probability category and results of contrasts comparing mean occupancy among presence probability categories for 363 nest boxes in West Virginia.

\begin{tabular}{lccc}
\hline Model value & $N$ & Mean & SE \\
\hline Optimal & 179 & 0.020 & 0.003 \\
Marginal & 92 & 0.009 & 0.003 \\
Submarginal & 92 & 0.008 & 0.001 \\
Contrast statements & & $P$ & \\
Optimal - Marginal & & 0.002 & \\
Optimal - Submarginal & & 0.008 & \\
Marginal - Submarginal & & 0.692 & \\
\end{tabular}


Table 2. Comparison of mean Glaucomys sabrinus fuscus nest box occupancy among seasons and results of contrasts comparing mean occupancy for 636 nest boxes in West Virginia.

\begin{tabular}{lccc}
\hline Season & $N^{\mathrm{a}}$ & Mean occupancy $^{\mathrm{b}}$ & $\mathrm{SE}$ \\
\hline Spring & 4,865 & 0.023 & 0.002 \\
Summer & 881 & 0.018 & 0.005 \\
Fall & 4,779 & 0.010 & 0.001 \\
Winter & 325 & 0.000 & 0.000 \\
Contrast statements & & $P$ & \\
Winter - spring & & $<0.001$ & \\
Winter - summer & & 0.062 & \\
Winter - fall & & 0.178 & \\
Spring - summer & & 0.330 & \\
Spring - fall & & 0.002 & \\
Summer - fall & & 0.025 & \\
\end{tabular}

${ }^{\text {a }} N$ is the number of nest box checks

${ }^{\mathrm{b}}$ Occupancy is defined as the proportion of nest box checks for each nest box that resulted in a G.s. fuscus capture 
Table 3. Comparison of mean numbers of Glaucomys sabrinus fuscus found among seasons and results of contrasts comparing mean numbers among seasons from 10,850 checks of 636 nest boxes in West Virginia.

\begin{tabular}{lccc}
\hline & $N$ & Mean $^{\text {a }}$ & SE \\
Season & 4,865 & 0.052 & 0.006 \\
\hline Spring & 881 & 0.048 & 0.014 \\
Summer & 4,779 & 0.021 & 0.004 \\
Fall & 325 & 0.000 & 0.000 \\
Winter & & $P$ & \\
Contrast statements & & $<0.001$ & \\
Winter - spring & & 0.028 & \\
Winter - summer & & 0.272 & \\
Winter - fall & & 0.697 & \\
Spring - summer & & 0.006 & \\
Spring - fall & & 0.027 & \\
Summer - fall & & & \\
& & & \\
\hline
\end{tabular}

${ }^{\mathrm{a}}$ Mean number of G.s. fuscus per nest box check 


\section{FIGURE LEGEND}

Figure 1. Graph showing the relationship $(r=0.119, P<0.001)$ between occupancy and predicted occupancy of 363 nest boxes in West Virginia. 


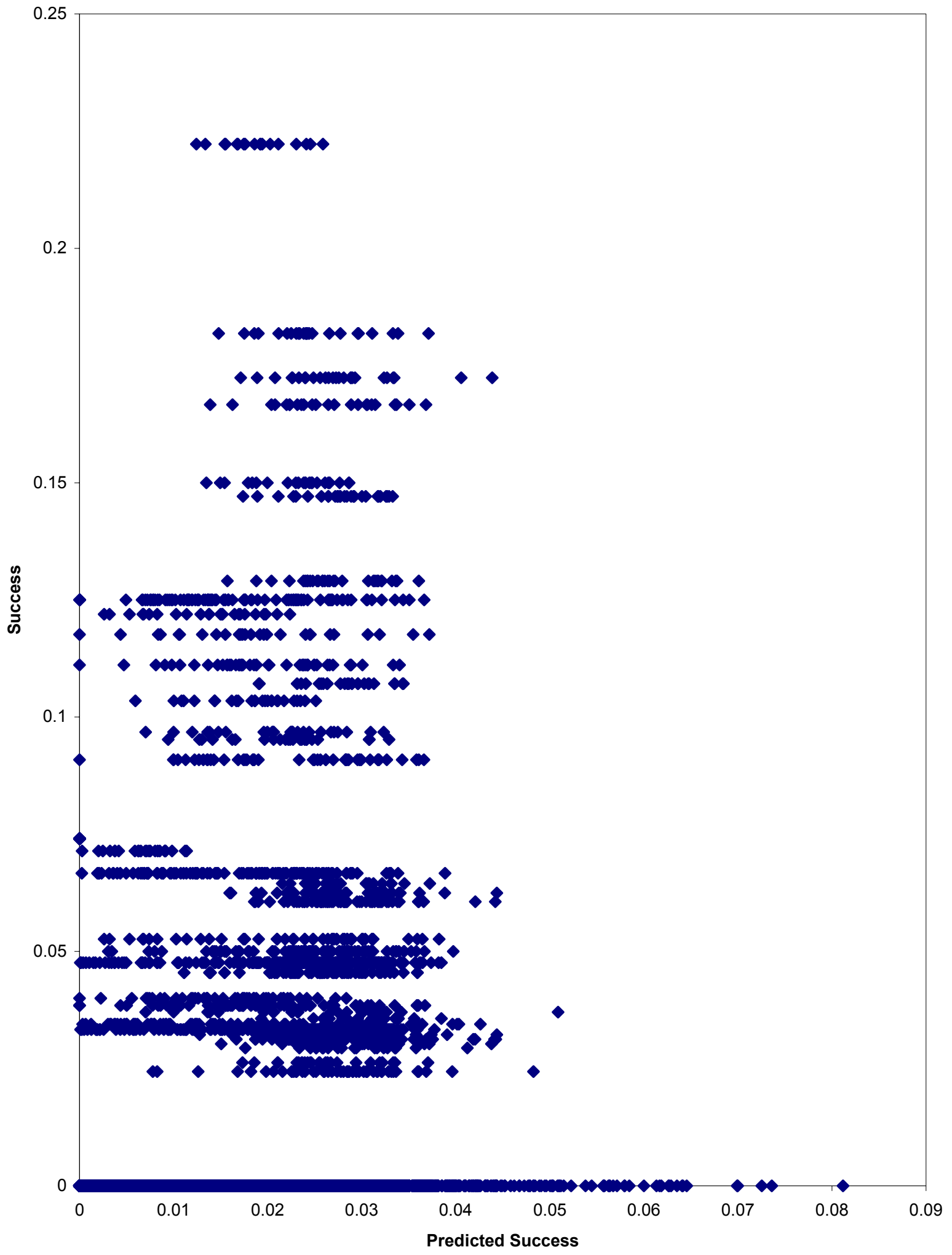


CHAPTER 3 - HABITAT MANAGEMENT RECOMMENDATIONS FOR THE ENDANGERED WEST VIRGINIA NORTHERN FLYING SQUIRREL (GLAUCOMYS SABRINUS FUSCUS) AT KUMBRABOW STATE FOREST, WEST VIRGINIA

\section{INTRODUCTION}

West Virginia's montane forest has been permanently altered by both climatic and anthropogenic factors. During the Pleistocene period, which occurred from 2 million to 14,000 years ago, glaciers advanced and retreated south and north several times, forcing the advance and retreat of species (Yahner 1995). During this period, 18,000 years ago, the montane red spruce (Picea rubens) forest of the eastern United States extended as far as modern day Tennessee, North Carolina, Missouri, Ohio, and Pennsylvania (Yahner 1995). The northern extent of red spruce was adjacent to the Laurentide ice sheet (Yahner 1995). During a warm postglacial era 5,000 years ago, vegetation was displaced into higher elevations by approximately $380 \mathrm{~m}$, causing vegetation change and extinction of plant and animal species (Whittaker 1956).

The European settlers altered the remaining montane forests further. Prior to settlement the only disturbances to the forest were the creation of small clearings by Native Americans (Stephenson 1993) and small gaps created by windthrown, diseased, or lightning struck trees (White et al. 1985, Bonnicksen 2000). The isolated patches of red spruce were isolated further when the area was logged in the late 1800s-early 1900s (Stephenson 1993). From 1880 to 1930, as a consequence of the extensive use of railroads for logging, the forest was plagued with fires initiated by sparks from the locomotives (Stephenson and Clovis 1983, White and Cogbill 1992). Additionally, livestock producers repeatedly burned cutover forests to create summer range (Stephenson 1993). Fires started by locomotives and later fires for livestock grazing further degraded soil conditions by consuming the humus layer characteristic of the montane ecosystem (Clarkson 1964). The removal of red spruce allowed for the expansion and proliferation of 
yellow birch (Betula allegheniensis) into areas where it either had been absent or was only a small component of the forest (Walker 1999). The degraded red spruce forests converted to lowquality northern hardwood forests or shrub-dominated glades (Stephenson 1993). Pielke (1981) estimates that red spruce was widespread above $910 \mathrm{~m}$ and dominant in forests above $1,220 \mathrm{~m}$ in the Central Appalachians prior to the onset of widespread logging in late $19^{\text {th }}$ Century. Red spruce currently is found scattered in West Virginia at elevations above 1,000 m (Core 1966, Stephenson and Clovis 1983).

The Appalachian montane forest is now considered one of the most threatened forested ecosystems in the United States (Christensen et al. 1996). In West Virginia, these forests have declined from greater than 200,000 ha in the mid 1800 s to a current distribution of 20,000 ha (Core 1966, Stephenson and Clovis 1983, Stephenson 1993). The forest continues to face threats to its survival. Destructive factors such as: atmospheric acid deposition, the hemlock adelgid (Adelges tsugae), high densities of white-tailed deer, surface mining, and recreational/secondhome development all are negatively affecting the health and future of the forest (Friedland et al. 1984, Schroeder 1988, McLaughlin et al. 1990, Michael 1992, Mohnen 1992, White and Cogbill 1992, McDonald 1993, Fredrickson 1998, Jenkins et al. 1999, Odom et al. 2001). In spite of the factors inhibiting spruce forest health and restoration, after one century without widespread fires, evidence suggests that the remaining montane forests may be partially restoring themselves and that this could be accelerated through management (Schuler et al. 2002). The presence of understory red spruce and eastern hemlock in low-quality northern hardwood forests suggests that thinning of the overstory could be used to release these species in the understory (Schuler et al. 2002). Planting of red spruce seedlings also may be used to accelerate restoration efforts. Red 
spruce seedlings have been successfully established in cut-over forests in North Carolina with survival rates of $85 \%$ after the fifth year post-planting (Korstian 1937).

Restoration of the montane forest would have a significant impact on the flora and fauna within this ecosystem. These remaining spruce forests may have some characteristics of mature montane forests, as is suggested by the presence of wildlife species that are thought to prefer these characteristics. These species include the West Virginia northern flying squirrel (Glaucomys sabrinus fuscus) and the Cheat Mountain salamander (Plethodon nettingi), both listed as federally protected species. Increased area in montane forests also would benefit other species of concern such as the saw-whet owl (Aegolius acadicus), northern goshawk (Accipter gentiles), and snowshoe hare (Lepus americanus). In addition to these charismatic fauna, several rare endemic insect and spider species, and probably those yet to be discovered, also depend on the presence of overstory red spruce (Acciavatti et al. 1993).

Northern flying squirrels of the eastern United States are closely associated with montane forests. They have been greatly affected by the changes to the forest. Fragmentation of habitat in the Appalachians has led to two distinct subspecies, G.s. fuscus and G.s. coloratus, both federally endangered (Wells-Gosling and Heaney 1984, USFWS 1990). These populations persist in highly disjunct and isolated subpopulations with little dispersal within subpsecies. Corridors linking the forests would not only enable movement among source and sink populations, but also increase the amount of habitat available to the species.

G.s. fuscus is found in disjunct patches of montane forest in West Virginia and Virginia. It is believed to select forests with overstory conifers, large snags, and an abundance of coarse woody debris (Browne et al. 1999). Overstory conifers are used by flying squirrels as both sites for leaf nests (Wells-Gosling and Heaney 1984) and launch points for gliding (Mowrey and 
Zasada 1984). Flying squirrels are secondary cavity nesters that use large snags with cavities for nest sites and refugia (Wells-Gosling and Heaney 1984). The presence of coarse woody debris is an important component of G.s. fuscus habitat because it supplies moist microhabitat necessary for the growth of the hypogeous and epigeous fungi that comprise the majority of the flying squirrel's diet (Loeb et al. 2000, Mitchell 2001).

Based on our knowledge of ecological requirements, G.s. fuscus would benefit from restoration of montane forests. Initially, it is more feasible to manage for forest expansion at a small scale rather than across a landscape. After small expansion projects have proven successful then larger scale management may become preferable. As an example of how these management objectives may be accomplished on a small scale I have examined Kumbrabow State Forest (KSF), an area with known G.s. fuscus populations, and identified areas that are candidates for montane forest restoration.

\section{RECOMMENDATIONS FOR KUMBRABOW STATE FOREST}

Kumbrabow State Forest is a 3,840 ha state forest on Rich Mountain in the Allegheny Mountain and Plateau physiographic sub-province in Randolph County, West Virginia, near the town of Helvetia (Fig. 1). The region is characterized by steep ridges running southwest to northeast. The area is mostly forested consisting of red maple (Acer rubrum), sugar maple (A. saccharum), yellow birch, American beech (Fagus grandifolia), Fraser magnolia (Magnolia fraseri), and black cherry (Prunus serotina; Stephenson 1993). Montane forests are found at elevations over 1,000 m (Core 1966, Stephenson and Clovis 1983, Bailey and Ware 1990, Stephenson 1993, Hornbeck and Kochenderfer 1998, and Schuler et al. 2002). KSF primarily is covered with second- and third-growth northern hardwood forest and montane forest aged 70 to 100 years. Elevation ranges from 700 to $1,195 \mathrm{~m}$. 
Although many micro-habitat requirements of G.s. fuscus remain unknown, habitat use has been studied and quantified at a landscape scale. Menzel (2003) used characteristics of known G.s. fuscus habitats to create a likelihood of presence model. Elevation and the presence or absence of spruce forest or spruce-hardwood forest were used to create a logistic equation that corresponded to probability of G.s fuscus presence. The resulting probabilities are classified as submarginal (0-49\%), marginal (50-75\%), or optimal (76-100\%). When this model was applied to KSF using geographic information systems coverage at a 0.09 ha resolution, 602.2 ha $(15.7 \%)$ were considered optimal, and 757.2 ha (19.7\%) were considered marginal (Table 1 and Fig. 2). Currently, the average predicted probability of West Virginia northern flying squirrel presence for $\mathrm{KSF}$ is $41 \%$.

Restoring the montane forests at KSF would require a modest removal of the overstory. The forest could be expanded by removing single trees and small groups of trees from the overstory to mimic naturally created gaps resulting from windthrow, lightning, and disease. Historically, gaps created by the fall of three or fewer trees often created a gap of 15 to $150 \mathrm{~m}^{2}$ (White et al. 1985). It is believed that these occasional gaps in the overstory were required for red spruce to obtain overstory status (White et al. 1985). The removal of large overstory trees results in the creation of gaps for the release of mid- and understory trees, more complex vertical structure of recruitment, the creation of snags and large coarse woody debris if the trees are not removed.

Within the montane forest stands, KSF has sapling to overstory-sized eastern hemlock (Tsuga canadensis), but most stems are found in the midstory. In areas where hemlock is not directly outcompeting spruce for resources, they should be left standing. It is probable that the hemlock adelgid ultimately will decimate these trees (T. Jones, West Virginia Division of 
Natural Resources, personal communication). Once this has happened, the trees eventually will fall and create more gaps in the forest and add to the coarse woody debris.

I have identified the following three areas of KSF that, if managed for montane forest characteristics, would benefit G.s. fuscus. The restoration of these stands on montane forests would expand the current G.s. fuscus habitat on KSF (Table 2). These areas were chosen based on their potential to expand current northern flying squirrel habitat, current species composition, and logging equipment accessibility. Much of the area to be released has red spruce present in the under- and midstory. Removing $30-60 \%$ of the basal area of the overstory hardwoods would allow the red spruce to grow into the overstory (T. Jones, WVDNR, personal communication). Similarly, the removal of understory and midstory trees that are directly shading or outcompeting understory red spruce would allow increased growth of the spruce.

\section{Headwaters of Potato Hole}

The area at the headwaters of Potato Hole currently has a small patch of forest with overstory red spruce and other characteristics indicative of G.s. fuscus habitat. I have identified an adjacent 3.9 ha site that can be managed for similar conditions (Fig. 3). This site currently includes 1.8 ha (46.2\%) that are considered optimal under the northern flying squirrel model. This is the only portion of the selected area that currently has overstory red spruce. The red spruce ranges from seedlings to pole-sized. Although optimal, the 1.8 ha mixed stand could be improved by releasing the under- and midstory spruce. The remaining 2.1 ha is an adjacent submarginal hardwood stand that has the potential to become optimal flying squirrel habitat. The average probability of northern flying squirrel presence for the site could be increased from $47 \%$ (submarginal) to $79 \%$ (optimal). 
This site could be improved by a moderate removal of the overstory trees. As a result of this release, the spruce in the midstory will respond with an increased primary growth rate allowing it to reach the overstory (Schuler et al. 2002). After an overstory thinning removing 30$60 \%$ of the overstory basal area, the hardwood stand would benefit from the planting of red spruce seedlings at a density of 250 trees per hectare. The diversity of red spruce tree heights currently in the mixed stand suggests that the forest will maintain its complex vertical structure after its initial release. This site has snags present, but a portion of the abundant Fraser magnolia and American beech trees should be deadened to create more snags for G.s. fuscus nest sites.

Any logging conducted at the headwaters of Potato Hole will require the construction of a road into the area. The areas I propose are not adjacent to the headwaters of Potato Hole, so there should be no riparian management restrictions.

\section{Rich Mountain Fork}

The Rich Mountain Fork site is 3.6 ha on an expansive flat area along the Rich Mountain fire trail (Fig. 4). This site currently has 0.7 ha (20.0\%) of mixed forest that are optimal flying squirrel habitat. If managed for overstory spruce, then the remaining 2.9 ha $(80.0 \%)$ hardwood forest could also become optimal habitat. The average probability of northern flying squirrel presence for the site could increase from $34 \%$ (submarginal) to $79 \%$ (optimal).

This site currently lacks the characteristics found in mature montane forests. Although the mixed stand contains occasional overstory red spruce, it stand mostly occurs in the understory. The hardwoods in the mixed stand are small and a thinning would constitute a precommercial thinning operation. The stand currently is lacking hardwood snags, but many of the maple trees could be converted to snags for future G.s. fuscus nest sites. 
The hardwood stand will require more preparation to become a montane forest. This stand contains sawtimber-sized black cherry. Although some black cherry trees could be removed to increase sunlight to the understory, a few mature trees should remain as the fruit is suspected to serve as important northern flying squirrel food source (C. Stihler, WVDNR, personal communication). This stand currently has no red spruce present in the understory or midstory, but after removal of $30-60 \%$ of the overstory basal area, red spruce seedlings could be planted at a density of 250 trees per hectare to reestablish the stand. These red spruce seedlings would need to be released again in the future with a thinning operation to help ensure that they successfully reach the overstory.

The location of this stand on the Rich Mountain fire trail will eliminate the need to create logging roads. Also, this stand is not adjacent to a stream, so no riparian management restrictions will need to be addressed.

\section{Mine Site}

The remains of the strip mine on the Rich Mountain fire trail include an 8.6 ha area adjacent to the Rich Mountain fire road (Fig. 5). Currently, 1.8 ha (20.9\%) is a mixed stand considered optimal under the northern flying squirrel model. With successful management for overstory red spruce, the remaining 6.8 ha $(79.1 \%)$ hardwood stand could also become optimal habitat. The average probability of northern flying squirrel presence could increase from 35\% (submarginal) to $79 \%$ (optimal).

The site would benefit from a modest removal (30-60\%) of the overstory basal area. A thinning of this intensity would allow ample amounts of sunlight to reach the understory. The site currently has a dense understory of spruce and a few spruce trees extending into the 
overstory in the mixed stand. The density of seedlings and saplings on the site would not necessitate the planting of more seedlings.

The overstory hardwoods present in this stand mostly are pulpwood sized, but some could be used as sawtimber. There are no sawtimber-sized cherry trees present. Furthermore, there are few hardwood snags. This stand would benefit from the deadening of some maple and beech trees to create future cavity trees for G.s. fuscus nest sites. The stand is on the Rich Mountain fire trail, so no new road would need to be built. However, this stand is adjacent to a first-order stream at the headwaters of Phillips Camp Run, so efforts would need to be undertaken to maintain the integrity of the riparian area.

\section{Other Sites}

Other areas of KSF also may be candidates for red spruce restoration. Areas of understory red spruce have been identified along the network of hiking trails and along main roads. Due to aesthetics, I do not recommend large scale logging operations of these areas. However, single tree removal of large overstory hardwoods would allow sunlight to penetrate the forest floor and facilitate the growth of the understory red spuce present. These trees could either be removed from the site, or killed in order to decrease shade and create more snags. Understory spruce also is found in remote and steep areas of the forest that are difficult to reach. Logging these areas would be costly and the methods and efforts required to reach these areas would necessitate disruption of current known and potential G.s. fuscus habitat.

\section{IMPLICATIONS FOR THE FUTURE}

Even with proper management, the establishment of new G.s. fuscus habitat at KSF will take several decades. However, since stand management will link current patches of habitat, it is 
expected that these managed areas might be used as travel corridors linking northern flying squirrel habitats. The stands are not expected to be optimal for G.s. fuscus until the red spruce reaches the overstory. Fortunately, red spruce is shade tolerant and can survive for years in the understory (White et al. 1985). A model created by White et al. (1985) suggests that $76 \%$ of red spruce saplings 1 to $2 \mathrm{~m}$ tall survive to the 2 to $4 \mathrm{~m}$ height class, therefore the initial release and subsequent planting of understory spruce seedlings at KSF will assist in the reestablishment of this species as a major component of the forest overstory. A second thinning after 30 to 50 years will help to facilitate this change (White et al. 1985). Similarly, hardwoods manipulated during the silvicultural treatments will take several years to become established cavity trees. Once the trees have succumbed to heart rot, woodpeckers must create and expand cavities that could later be used by flying squirrels.

The volume of coarse woody debris can be expected to increase as understory tree mortality rises with canopy closure and maturation. Thinning of the overstory would maximize the total volume of coarse woody debris added during the following 50 years (Schuler et al. 2002). More coarse woody debris would be added to the forest floor if, during logging operations, select trees were not removed, but deadened or felled and left on the forest floor (Schuler et al. 2002). The tops of the trees could be used for pulpwood while the bole remained on the forest floor.

Although 1,359 ha (35.4\%) of KSF currently are included in the West Virginia northern flying squirrel model, the restoration of the montane forest would increase this value. All of the area currently classified as marginal or optimal in the flying squirrel presence predictive model is mixed forest. If all of KSF were to become mixed forest, then 2,073 ha (54.0\%) would become optimal flying squirrel habitat while the remaining 1,767 ha (46.0\%) would become marginal 
habitat (Table 3). The average probability of West Virginia northern flying squirrel presence on KSF would increase to $76 \%$. It is unfeasible and unrealistic to expect that all of the areas of KSF that have the potential to become optimal or marginal northern flying squirrel habitat can be managed to that potential. The values represented here constitute a best-case scenario for the forest.

The northern flying squirrel predictive presence model is a tool that land stewards can use to better manage for the endangered species. No management decisions should be made solely on the results of the model. A thorough examination of the site should be conducted before any silvicultural practices are initiated. Proper use of the model and knowledge of the site will give managers insight into what treatments will best enhance the forest for the West Virginia northern flying squirrel.

After managed areas are established as mature montane forests, adjacent areas also can be managed for the same forest characteristics. This further expansion of the forest would increase the amount of suitable G.s. fuscus area and eventually link disjunct habitat patches. Although the forest never again will be as expansive as it was prior to logging, with careful management we can restore enough montane forests to help insure the survival of G. s. fuscus and the other species that depend on the forest.

\section{LITERATURE CITED}

Acciavatti, R.E., T.J. Allen, A.R. Miller, L.L. Pechuman, B.C. Kondrateiff, R.F. Kirchner, A.G. Wheeler, S.M. Clark, E. van der Berghe, and W.J. Arnold. 1993. Insects and spiders of the upland forest. Pp. 143-178 in S.L. Stephenson, ed., Upland Forests of West Virginia. McClain Printing, Parsons, West Virginia, USA. 
Bailey, C.M., and S. Ware. 1990. Red spruce forests of Highland County, Virginia: biogeographical considerations. Castanea 55:245-258.

Bonnicksen, T.M. 2000. America's ancient forests: From the Ice Age to the Age of Discovery. John Wiley and Sons, Inc. New York City, New York. United States. 594 pp.

Browne, R., P. Weigl, E. Eagleson, and J. Kelly. 1999. Mountaintops as islands: genetic variation among southern Appalachian populations of the endangered northern flying squirrel (Glaucomys sabrinus) (Mammalia: Sciuridae). Proceedings of the Appalachian biogeography symposium. Pp. 165-214.

Christensen, N.I., A.M. Bartuska, J.H. Brown, S. Carpenter, C.D. D'Antonio, R. Francis, J.F. Franklin, J.A. MacMahon, R.F. Noss, D.J. Parsons, C.H. Peterson, M.G. Turner, and R.G. Woodmansee. 1996. The report of the Ecological Society of America Committee on the scientific basis for ecosystem management. Ecological Applications 6:665-691.

Clarkson, R.B. 1964. Tumult on the mountains. McClain Printing. Parsons, West Virginia, United States.

Core, E.L. 1966. Vegetation of West Virginia. McClain Printing. Parsons, West Virginia, United States.

Fredrickson, T.S. 1998. Impacts of logging and development on central Appalachian forests. Natural Areas Journal. 18:175-178

Friedland, A.J., R.A. Gregory, L. Karenlampi, and A.H. Johnson. 1984. Winter damage to foliage as a factor in red spruce decline. Canadian Journal of Forest Research. 14:963965.

Hornbeck, J.W. and J.N. Kochenderfer. 1998. Growth trends and management implications for West Virginia's red spruce forests. Northern Journal of Applied Forestry 15:197-202. 
Korstian, C.F. 1937. Perpetuation of spruce on cut-over and burned lands in the higher southern Appalachian mountains. Ecological Monographs 7(1)125-167.

Jenkins, J.C., J.D Aber, and C.D. Canham. 1999. Hemlock wooly adelgid impacts on community structure and $\mathrm{N}$ cycling rates in eastern hemlock forests. Canadian Journal of Forest Research. 29:630-645.

Loeb, S.C., F.H. Tainter, and E. Cázares. 2000. Habitat associations of hypogeous fungi in the Central Appalachians: Implications for the endangered northern flying squirrel (Glaucomys sabrinus coloratus). American Midland Naturalist 144:286-296.

McDonald, B.R. 1993. Rare plants of the upland forest. Pp. 67-86 in S.L. Stephenson, ed., Upland Forests of West Virginia. McClain Printing, Parsons, West Virginia, USA.

McLaughlin, S., C.J. Anderson, N.T. Edwards, W.K. Roy, and P.A. Layton. 1990. Seasonal patterns of photosynthesis and respiration of red spruce saplings from two elevations in declining southern Appalachian stands. Canadian Journal of Forest Research. 20:485495.

Menzel, J.M. 2003. An examination of the habitat requirements of the endangered Virginia northern flying squirrel (Glaucomys sabrinus fuscus) by assessing nesting sites, habitat use, and the development of a habitat model. Dissertation, West Virginia University, Morgantown, West Virginia, USA.

Michael, E.D. 1992. Impact of deer browsing on regeneration of balsam fir in Canaan Valley, West Virginia. Northern Journal of Applied Forestry. 9:89-90.

Mitchell, D. 2001. Spring and fall diet of the endangered West Virginia northern flying squirrel (Glaucomys sabrinus fuscus). American Midland Naturalist 146:439-443. 
Mohnen, V.A. 1992. Atmospheric deposition and pollutant exposure of eastern U.S. forests. Pp. 64-124 In C. Eagar and M.B. Adams (eds.) Ecology and decline of red spruce in the eastern United States. Springer Verlag. New York City, New York, United States.

Mowrey, R.A., and J.C. Zasada. 1984. Den tree use and movements of northern flying squirrels in interior Alaska and implications for forest management. p. 351-356. In: W.R. Meehan, T.R. Merrell, Jr. and T.A. Hanley, (eds.). Fish and wildlife relationships in old growth forests: proceedings of a symposium. Bookmasters, Ashland, $\mathrm{OH}, 435 \mathrm{pp}$.

Odom, R.H., W.M. Ford, J.W. Edwards, C.W. Stihler, and J.M. J.M. Menzel. 2001. Developing a habitat model for the endangered Virginia northern flying squirrel (Glaucomys sabrinus fuscus) in the Allegheny Mountains of West Virginia. Biological Conservation. 99:245252.

Pielke, R.A. 1981. The distribution of spruce in west-central Virginia before logging. Castanea. 46:201-216.

Schroeder, F.G. 1988. Southern Appalachians. Pp. 106-107. In B. Krahl-Urban, H.E. Papke, K. Peters and C. Schimansky (eds) Forest decline. U.S. Environmental Protection Agency. Corvallis, Oregon, United States.

Schuler, T.M., W.M. Ford, and R.J. Collins. 2002. Successional dynamics and restoration implications of a montane coniferous forest in the central Appalachians, USA. Natural Areas Journal 22:88-98.

Stephenson, S.L. 1993. Upland Forests of West Virginia. McClain Printing, Parsons, West Virginia. , and J.F. Clovis. 1983. Spruce forests of the Allegheny Mountains in central West Virginia. Castanea 48:1-12. 
U.S. Fish and Wildlife Service. 1990. Appalachian Northern Flying Squirrels (Glaucomys sabrinus fuscus and Glaucomys sabrinus coloratus) Recovery Plan. Newton Corner, Massachusetts, USA.

Walker, L.C. 1999. The North American forests: Geology, ecology, and silviculture. CRC Press. Boca Raton, Florida, United States. 398 pp.

Wells-Gosling, N. and L.R. Heaney. 1984. Glaucomys sabrinus. Mammalian Species No.229:18.

White, P.S. and C.V. Cogbill. 1992. Spruce-fir forests of eastern North America. Pp. 1-39 in C. Eager and M.B. Adams, eds. Ecology and decline of red spruce in the eastern United States. Springer-Verlag, New York, New York, United States. , M.D MacKenzie, and R.T. Busing. 1985. Natural disturbance and gap phase dynamics in southern Appalachian spruce-fir forests. Canadian Journal of Forest Research. 15:233240.

Whittaker, R.H. 1956. Vegetation of the Great Smoky Mountains. Ecological Monographs. 26:180.

Yahner, R.H. 1995. Eastern deciduous forest: Ecology and wildlife conservation. University of Minnesota Press. Minneapolis, Minnesota, United States. 220 pp. 
Table 1. Area of Kumbrabow State Forest (3,840 ha) in Randolph County, West Virginia, that was included in the West Virginia northern flying squirrel model by J.M. Menzel (unpublished data).

\begin{tabular}{lccc}
\hline Classification & Likelihood of flying squirrel presence & Area (ha) & Percentage \\
& $76-100$ & 602.2 & 15.7 \\
Optimal & $50-75$ & 757.2 & 19.7 \\
Marginal & & & \\
& & $1,359.4$ & 35.4 \\
\hline
\end{tabular}


Table 2. Size and application of West Virginia northern flying squirrel model (J.M. Menzel unpublished data) to the areas proposed for understory red spruce release at Kumbrabow State Forest in Randolph County, West Virginia. Optimal sites have an estimated 76-100\% likelihood of northern flying squirrel presence.

Optimal

Site Name

Area (ha)

Area (ha) Percentage

Potato Hole

3.9

1.8

46.2

Rich Mountain Fork

3.6

0.7

20.0

Mine Site

8.6

1.8

20.9

Total

16.1

4.3

26.7 
Table 3. Area of Kumbrabow State Forest (3,840 ha) in Randolph County, West Virginia that could be managed for West Virginia northern flying squirrels under the model by J.M. Menzel (unpublished data).

\begin{tabular}{lccc}
\hline Classification & Likelihood of flying squirrel presence & Area (ha) & Percentage \\
& $76-100$ & $2,073.3$ & 54.0 \\
Optimal & $50-75$ & $1,766.7$ & 46.0 \\
Marginal & & & \\
& & $3,840.0$ & 100.0 \\
\hline
\end{tabular}




\section{FIGURE LEGEND}

Figure 1. Location of Kumbrabow State Forest in Randolph County, West Virginia.

Figure 2. Application of the West Virginia northern flying squirrel model (J.M. Menzel unpublished data) to Kumbrabow State Forest, Randolph County, West Virginia.

Figure 3.The Potato Hole area of Kumbrabow State Forest that is recommended for understory red spruce release (3.9 ha), and the West Virginia northern flying squirrel model (J.M. Menzel unpublished data).

Figure 4. The Rich Mountain Fork area of Kumbrabow State Forest that is recommended for understory red spruce release (3.6 ha), and the West Virginia northern flying squirrel model (J.M. Menzel unpublished data).

Figure 5. The Mine Site area of Kumbrabow State Forest that is recommended for understory red spruce release (8.6 ha), and the West Virginia northern flying squirrel model (J.M. Menzel unpublished data).

Figure 6. The potential West Virginia northern flying squirrel predictive presence values (J.M. Menzel unpublished data) for Kumbrabow State Forest if the entire forest were managed for overstory conifer trees. The result is 2,073 ha (54.0\%) of optimal area and 1,767 ha (46.0\%) of marginal area. 


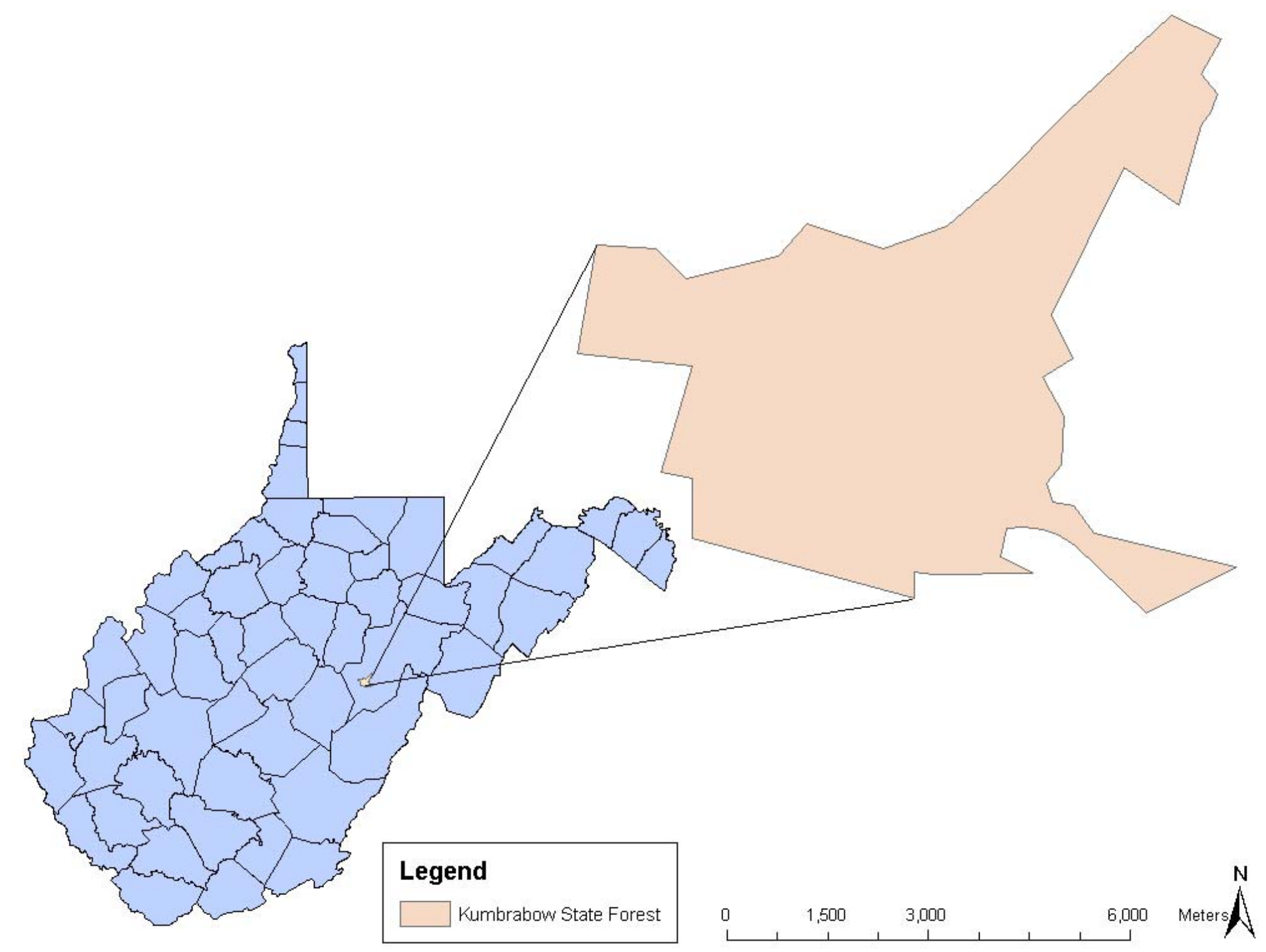




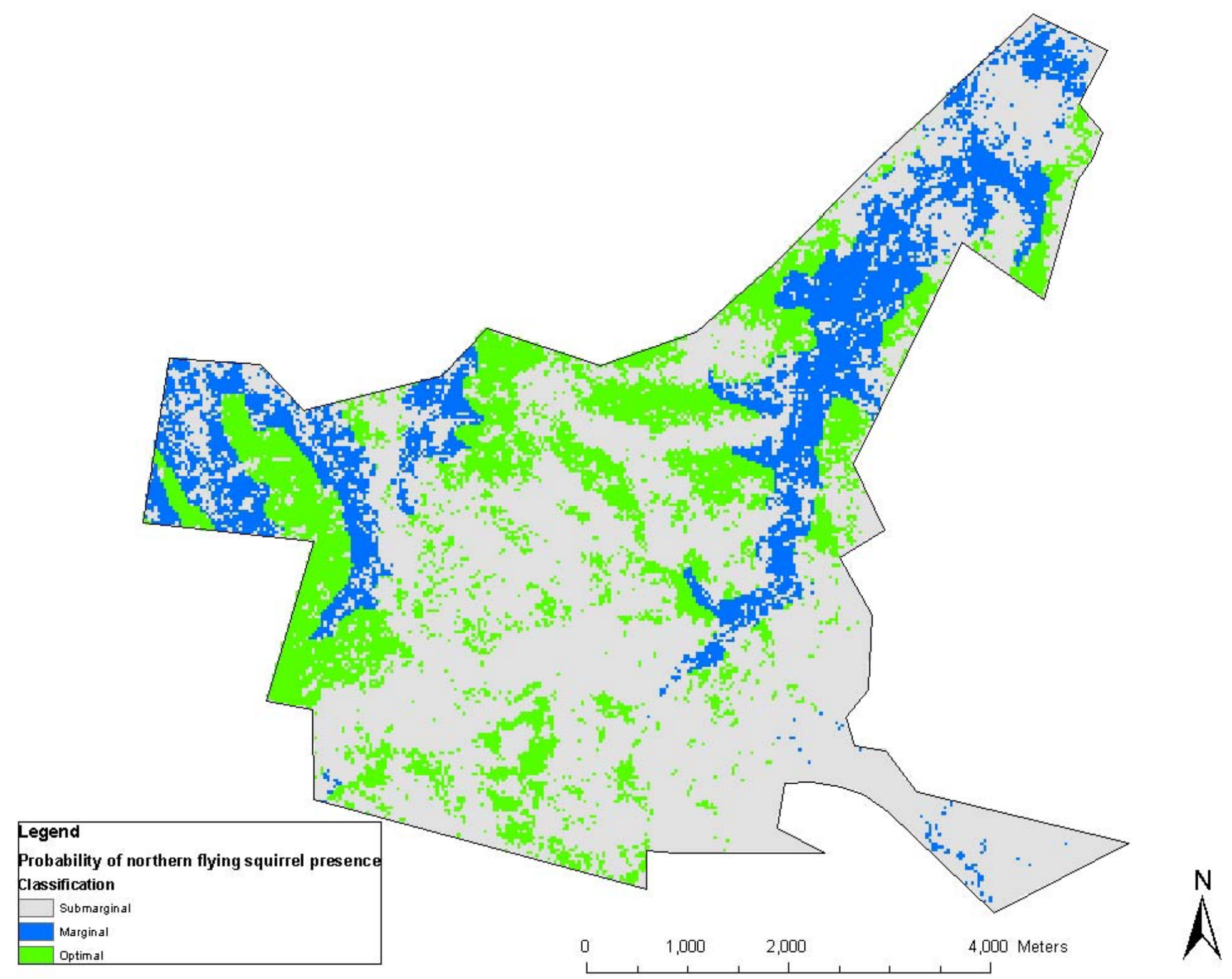




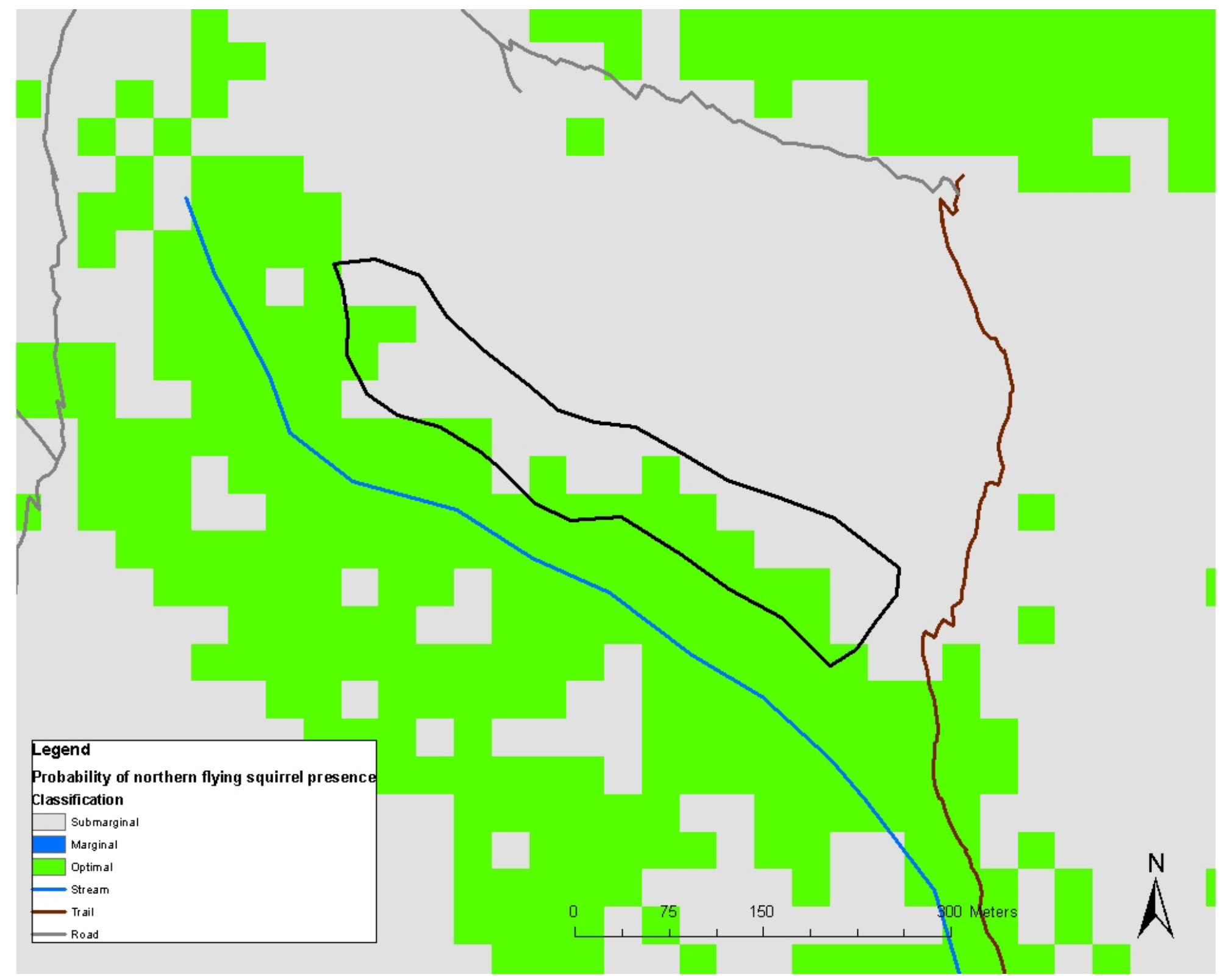




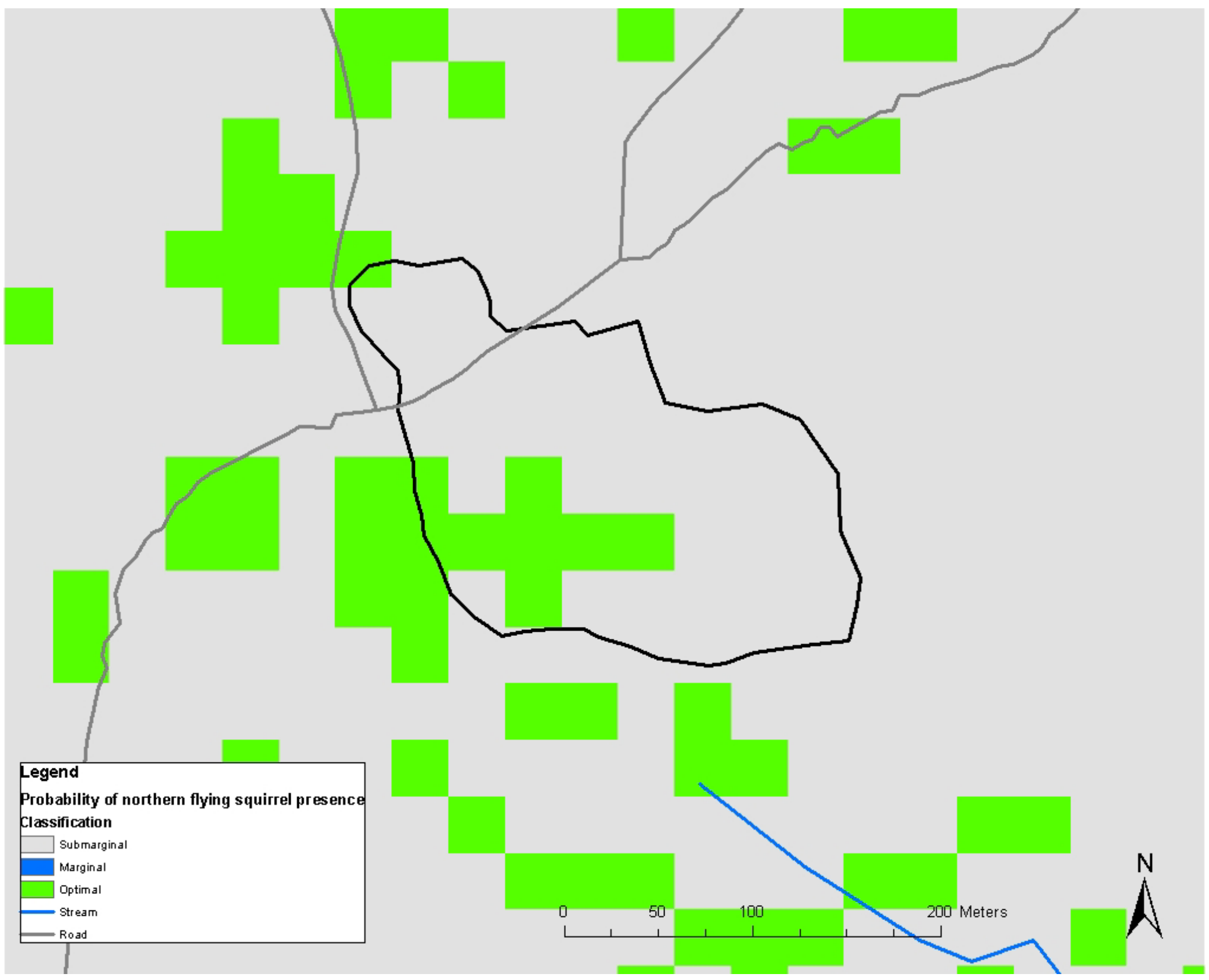




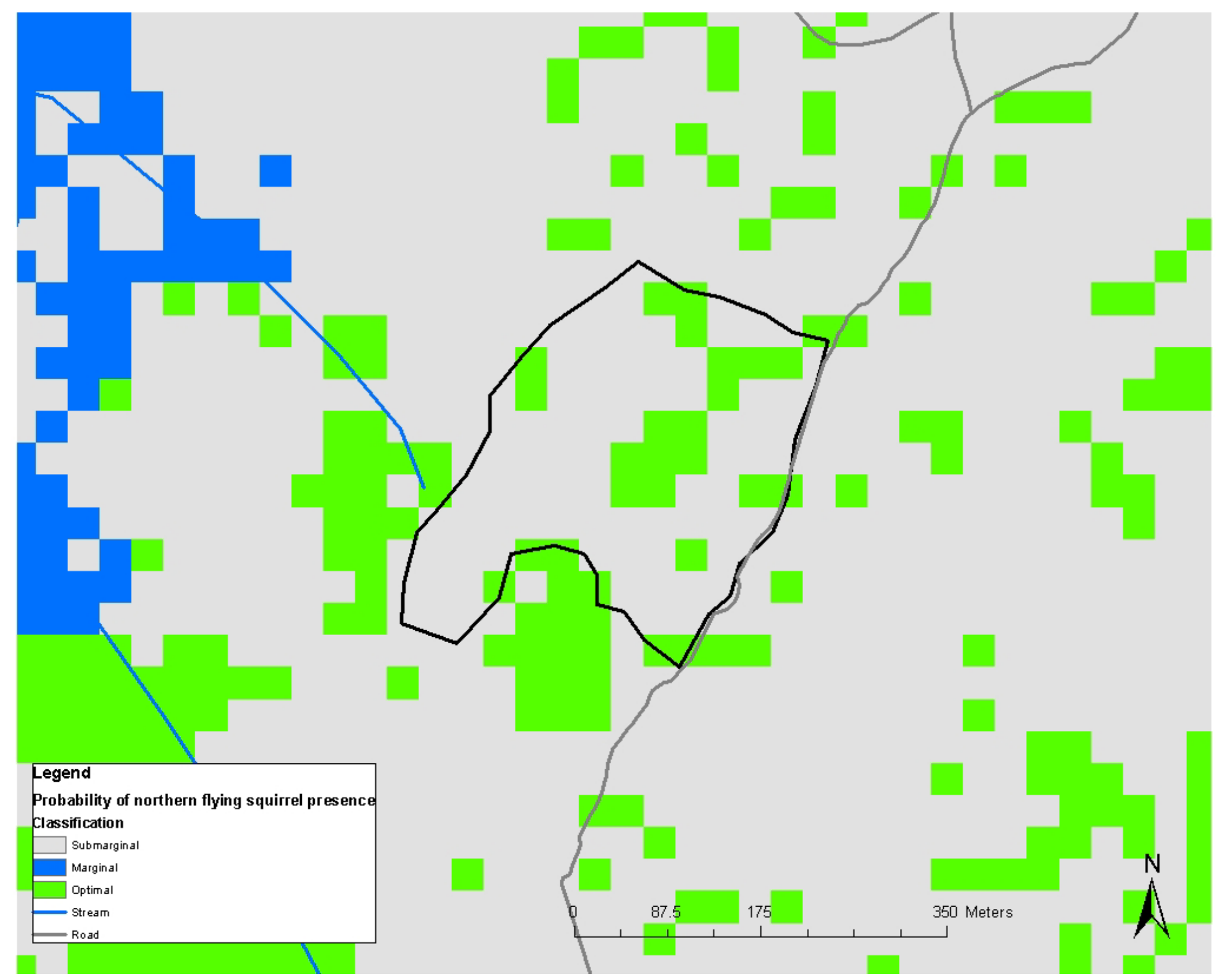




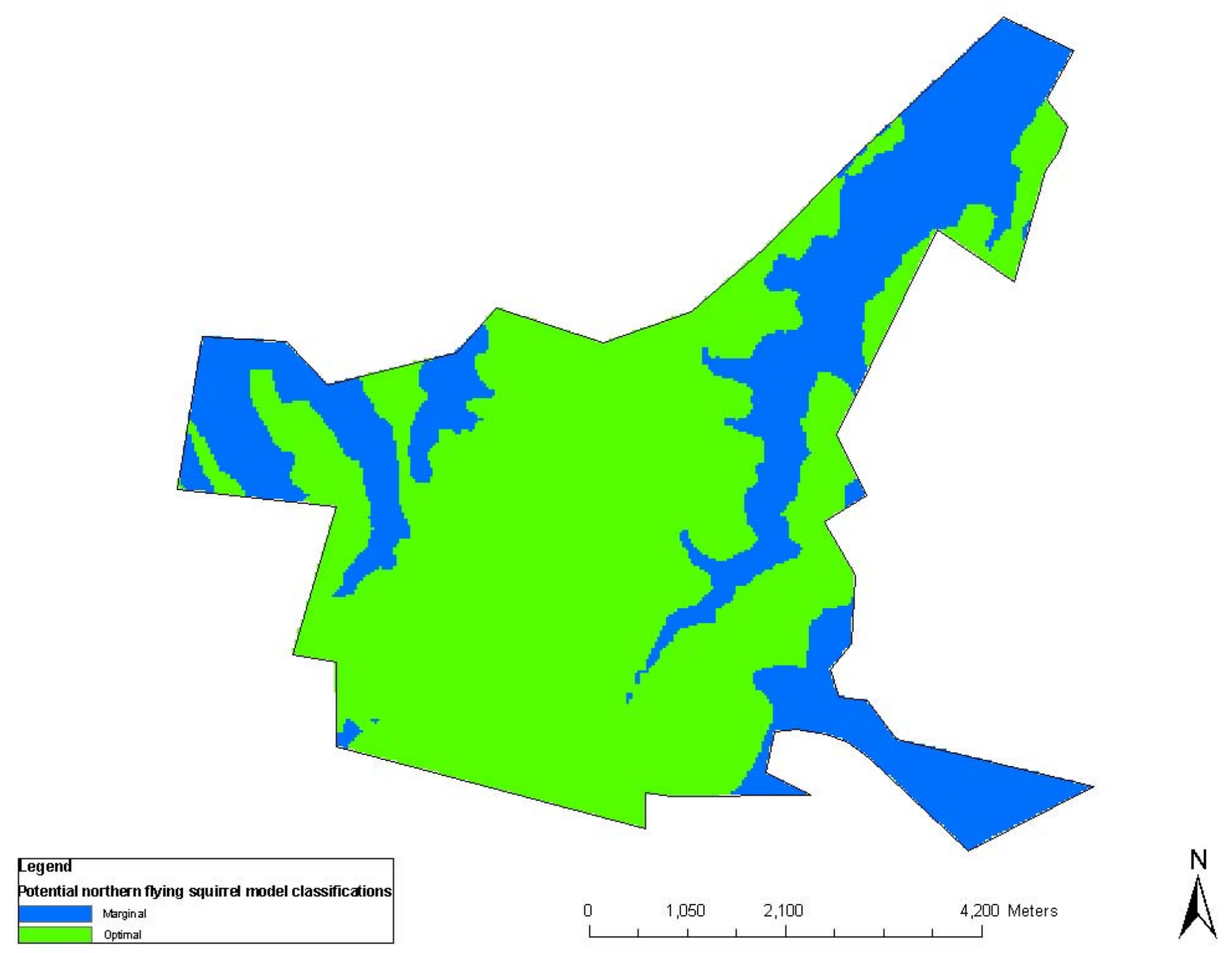

